\title{
Spread, Behavior, and Ecosystem Consequences of Conventional Munitions Compounds in Coastal Marine Waters
}

\section{OPEN ACCESS}

Edited by:

Antonio Tovar-Sanchez,

Consejo Superior de Investigaciones

Científicas (CSIC), Spain

Reviewed by:

Pablo Antonio Lara-Martin,

University of Cádiz, Spain

Julian Blasco,

Consejo Superior de Investigaciones

Cientificas (CSIC), Spain

*Correspondence:

Aaron J. Beck

ajbeck@geomar.de

Specialty section:

This article was submitted to Marine Biogeochemistry,

a section of the journal Frontiers in Marine Science

Received: 07 March 2018 Accepted: 09 April 2018 Published: 30 April 2018

Citation:

Beck AJ, Gledhill M, Schlosser C Stamer B, Böttcher C, Sternheim J, Greinert $J$ and Achterberg EP (2018)

Spread, Behavior, and Ecosystem Consequences of Conventional

Munitions Compounds in Coastal Marine Waters. Front. Mar. Sci. 5:141. doi: 10.3389/fmars.2018.00141

\author{
Aaron J. Beck ${ }^{1 *}$, Martha Gledhill ${ }^{1}$, Christian Schlosser ${ }^{1}$, Beate Stamer ${ }^{1}$, Claus Böttcher ${ }^{2}$, \\ Jens Sternheim ${ }^{2}$, Jens Greinert ${ }^{1,3}$ and Eric P. Achterberg ${ }^{1,3}$ \\ ${ }^{1}$ GEOMAR - Helmholtz Centre for Ocean Research Kiel, Kiel, Germany, ${ }^{2}$ Ministerium für Energiewende, Landwirtschaft, \\ Umwelt, Natur und Digitalisierung des Landes Schleswig-Holstein, Kiel, Germany, ${ }^{3}$ Christian-Albrechts University Kiel, \\ Institute of Geosciences, Ludewig-Meyn-Str, Kiel, Germany
}

Coastal marine environments are contaminated globally with a vast quantity of unexploded ordnance and munitions from intentional disposal. These munitions contain organic explosive compounds as well as a variety of metals, and represent point sources of chemical pollution to marine waters. Most underwater munitions originate from World Wars at the beginning of the twentieth century, and metal munitions housings have been impacted by extensive corrosion over the course of the following decades. As a result, the risk of munitions-related contaminant release to the water column is increasing. The behavior of munitions compounds is well-characterized in terrestrial systems and groundwater, but is only poorly understood in marine systems. Organic explosive compounds, primarily nitroaromatics and nitramines, can be degraded or transformed by a variety of biotic and abiotic mechanisms. These reaction products exhibit a range in biogeochemical characteristics such as sorption by particles and sediments, and variable environmental behavior as a result. The reaction products often exhibit increased toxicity to biological receptors and geochemical controls like sorption can limit this exposure. Environmental samples typically show low concentrations of munitions compounds in water and sediments (on the order of $\mathrm{ng} / \mathrm{L}$ and $\mu \mathrm{g} / \mathrm{kg}$, respectively), and ecological risk appears generally low. Nonetheless, recent work demonstrates the possibility of sub-lethal genetic and metabolic effects. This review evaluates the state of knowledge on the occurrence, fate, and effect of munition-related chemical contaminants in the marine environment. There remain a number of knowledge gaps that limit our understanding of munitions-related contaminant spread and effect, and the need for additional work is made all the more urgent by increasing risk of release to the environment.

Keywords: underwater munitions, discarded military munitions, unexploded ordnance, UXO, trinitrotoluene, TNT, RDX, HMX

\section{INTRODUCTION}

Coastal marine environments are contaminated globally with unexploded ordnance and munitions from intentional disposal (Figure 1), but their distribution and condition are not well known (Sanderson et al., 2017). Coastal waters are particularly impacted by relic munitions resulting from the two World Wars (WWI and WWII), and the German portions of the North Sea and 


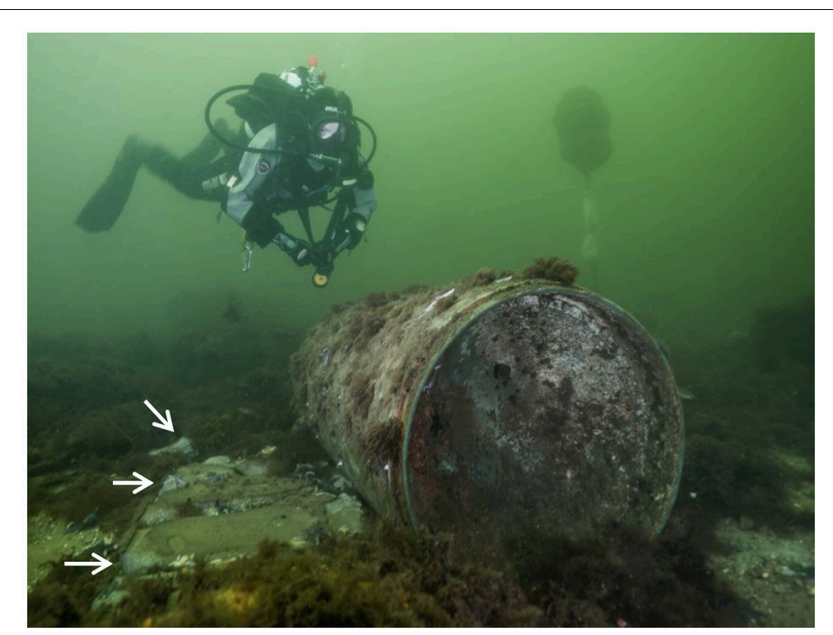

FIGURE 1 | German mine (most likely a BM 1000 parachute mine, Wichert, 2018) on the seafloor in the Baltic Sea, weighing approximately $500 \mathrm{~kg}$, with scientific diver for scale. The small gray objects in the sand near the ground mine (arrows) are likely intact, exposed pieces of explosives remaining after low-order detonation of other mines in the area (Photo: J. Ulrich).
Naidu, 2007), with the aim of summarizing and clarifying biogeochemical processes likely to be important for munition compound transport and fate specifically in coastal marine systems.

Here we focus on the chemical constituents that typically occur in conventional munitions present in the marine environment. In particular, this includes organic explosive compounds, metalloorganic explosives, and metals used in casings and housings of munitions. The explosive compounds considered here are the nitroaromatic 2,4,6,-trinitrotoluene (TNT), and the nitramines hexahydro-1,3,5-trinitro-1,3,5triazine (RDX, or hexogen) and octahydro-1,3,5,7-tetranitro1,3,5,7-tetreazocine (HMX, or octogen). Some more sensitive metaloorganic compounds used as initiators for detonation of secondary explosives will also be discussed (e.g., fulminates, azides, and styphnates of mercury, lead, and silver), although their marine environmental behavior and fate is very poorly known. There are other explosive compounds used historically (e.g., tetryl and ammonium picrate), or which are more recently developed (e.g., hexanitrohexaazaisowurtzitane), but TNT, RDX, and HMX represent a major portion of munition material present in terrestrial and marine environments (US EPA, 2012).

\section{CHEMICALS IN CONVENTIONAL MUNITIONS FOUND IN THE SEA, AND SCALE OF THE PROBLEM}

The explosive TNT was developed in 1863 (Wilbrand, 1863), and adapted for military use in 1902 (Travis, 2015). Nitrate for use in nitrated explosives (such as TNT) and agriculture during WWI was primarily sourced from saltpeter mines in Chile. Demand for nitrate during wartime was so fundamental that industrial nitrogen fixation (Haber-Bosch process) was developed in Germany following British blockade of the Chilean mines (Erisman et al., 2008). Similarly, the high demand for toluene in explosives production led to development of industrial production methods using petroleum instead of traditional methods utilizing coal tar (Love and Pfennig, 1951). Peak global toluene production during WWII exceeded typical peace time rates by nearly two orders of magnitude (Speight, 2011). Given this scale of production, the magnitude of munitions contamination in coastal waters (Nehring, 2005; Nixon, 2009; Böttcher et al., 2011) is perhaps less surprising.

Explosives such as TNT are relatively stable, and detonation is induced by a primary explosive, or so-called initiator. The most common primary explosives in use currently are $\mathrm{Pb}$ styphnate and $\mathrm{Pb}$ azide (Oyler et al., 2015), although $\mathrm{Hg}$ fulminate was the predominant primary explosive used historically. During the two WWs, Hg fulminate was used to such an extent that munitions consumed as much as $15 \%$ of the global Hg production (Figure 2) (Horowitz et al., 2014). Historical use of $\mathrm{Hg}$ fulminate has been phased out in favor of $\mathrm{Pb}$ compounds (Huynh et al., 2006; Matyáš and Pachman, 2012), but there remains evidence that $\mathrm{Hg}$ based explosives compounds are still used and continue to enter the environment (Kyllönen et al., 2014). 


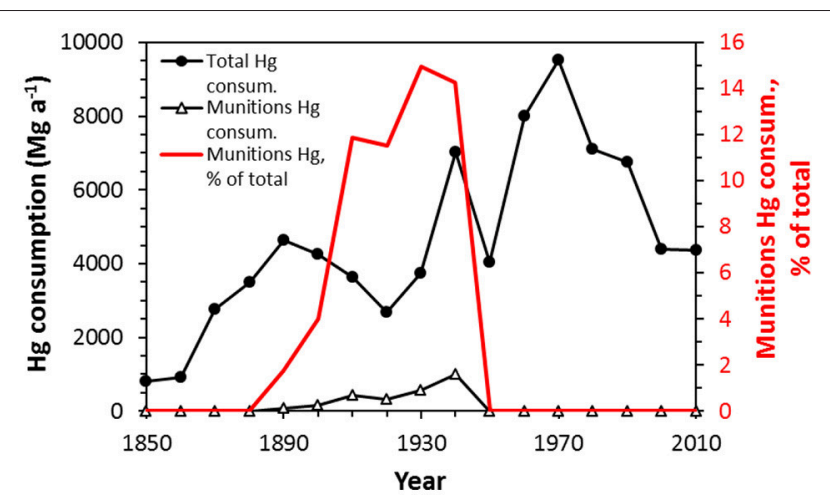

FIGURE 2 | Global annual mercury consumption, annual Hg consumption for munitions, and proportion used in munitions. Mercury-based explosives show a peak in production during the period of WWI and WWII. Redrawn after Horowitz et al. (2014).

Conventional munitions also comprise a substantial quantity of other metals for driving bands, casings, and fuses, including iron, copper, aluminum, lead, and zinc (Bausinger et al., 2007; Tornero and Hanke, 2016). Callaway et al. (2011) estimated that the metal load associated with munitions dumped in the North Channel (UK) in 1949 alone was comparable to 52 years of normal anthropogenic input to the entire Irish Sea.

\section{GLOBAL DISTRIBUTION AND LOCAL MAPPING}

Intentional disposal of munition material (discarded munition material; DMM) in the ocean was the major disposal method for unusable or unwanted munitions until promulgation of the Convention on the Prevention of Marine Pollution by Dumping of Wastes and Other Matter in 1972 (Oslo Convention, and 1975 London Convention of the same name) and the US Marine Protection, Research, and Sanctuaries Act of 1972 (Carton and Jagusiewicz, 2011). As a result, most munition dumpsites are in coastal waters of regions that were heavily involved in WW I and II, including Europe, North America, and the southwest Pacific (Figure 3). In contrast, to our knowledge, the coastal oceans surrounding South America and Africa are relatively unimpacted by relic DMM.

In addition to DMM, unexploded ordnance (UXO) is present at many marine sites in the form of armed and deployed but undetonated mines, failed detonations (duds), and wrecks of ships carrying munitions (Monfils et al., 2006; Aker et al., 2012). Such UXO is more likely to be a source of metals-based primary explosives than DMM because the latter were usually not armed or fully assembled before disposal. More than 3,800 WWII-era shipwrecks are present in the East Asian-Pacific region alone (Monfils et al., 2006), many loaded with UXO, though the amount is not known. It has further been estimated that some 20$30 \%$ of ammunition fired during the two WWs failed to detonate (GICHD, 2016), suggesting a large quantity of WW-era UXO may exist in coastal marine environments.
The location and extent of marine DMM and UXO are very poorly documented, and efforts to evaluate human impacts in the ocean have noted that munitions dumpsites are one of the least well-constrained challenges (Benn et al., 2010). In some cases, even where dumping sites are known, the specificity of DMM quantities can range from number of bombs and their exact identification to "1-2 barges" of material (Brankowitz, 1989). One report stated, "It appears unlikely that a completely accurate record of US dumping activities can be reconstructed" (p. 33) (MEDEA, 1997). Chemical weapons (CW) were usually dumped in assembled munitions or in association with conventional munition explosives, and more complete reports of chemical weapons dumping are often more readily available than for conventional weapons (e.g., Plunkett, 2003, but cf. Krohn, 1994). Nonetheless, there can remain substantial uncertainty about the undersea presence of chemical munitions even where relatively good records of disposal exist (Brewer and Nakayama, 2008; Brewer et al., 2008; Wichert, 2010).

The distribution and magnitude of UXO are similarly difficult to constrain, but it represents an additional source of marine munitions from wars early in the twentieth century as well as more recent conflicts (e.g., in the Middle East). To our knowledge, there is very little public information available on the presence of UXO or DMM in the Red Sea and Persian Gulf region, but there are indications that it may be prevalent following regional wars since the 1990's (Fowler, 1993; Nadim et al., 2008; United Nations General Assembly, 2013; National Geospatial-Intelligence Agency, 2017). Although records are incomplete, the map shown in Figure 3 (including reports of DMM, UXO, and CW) illustrates the global extent of munitions material in the marine environment.

An additional important consideration is actions that can lead to unencased or exposed munition material on the seafloor. Blow-in-place (BIP) methods of in situ munition disposal (e.g., Koschinski and Kock, 2009) often result in incomplete (loworder) detonation, leaving substantial quantities of the explosive material in the environment (NATO, 2010; Kalderis et al., 2011) (Figure 1). For example, numerous $250-500 \mathrm{~kg}$ mines were intentionally detonated underwater at one site in the Baltic Sea in 2009, but the low-order detonation of several mines left substantial quantities of intact, exposed explosive material on the seafloor [Figure 1; "Schiesswolle," a combination of TNT, RDX, and aluminum powder (Haas and Thieme, 1996; Pfeiffer, 2009)].

Given the lack of constraint surrounding the extent and quantity of munitions disposed in the marine environment, direct inspection is often required in order to evaluate the risk. Site-specific or limited regional efforts using geophysical techniques have been successful in mapping the local distribution of munitions on the seafloor (10-1,000 m scale) (Decarlo et al., 2007; CIRIA, 2016; Czub et al., 2018). Optical imagery also produces high resolution images and can accurately identify munitions objects, but is quite limited in terms of its spatial scope (10 s of meters scale) (Shihavuddin et al., 2014). Sidescan sonar can provide particularly striking high-resolution images of submerged munitions (Frenz, 2014; Czub et al., 2018), but uncertainties in e.g., the layback (wire length, angle), limit the absolute accuracy with which objects can be geo-referenced 


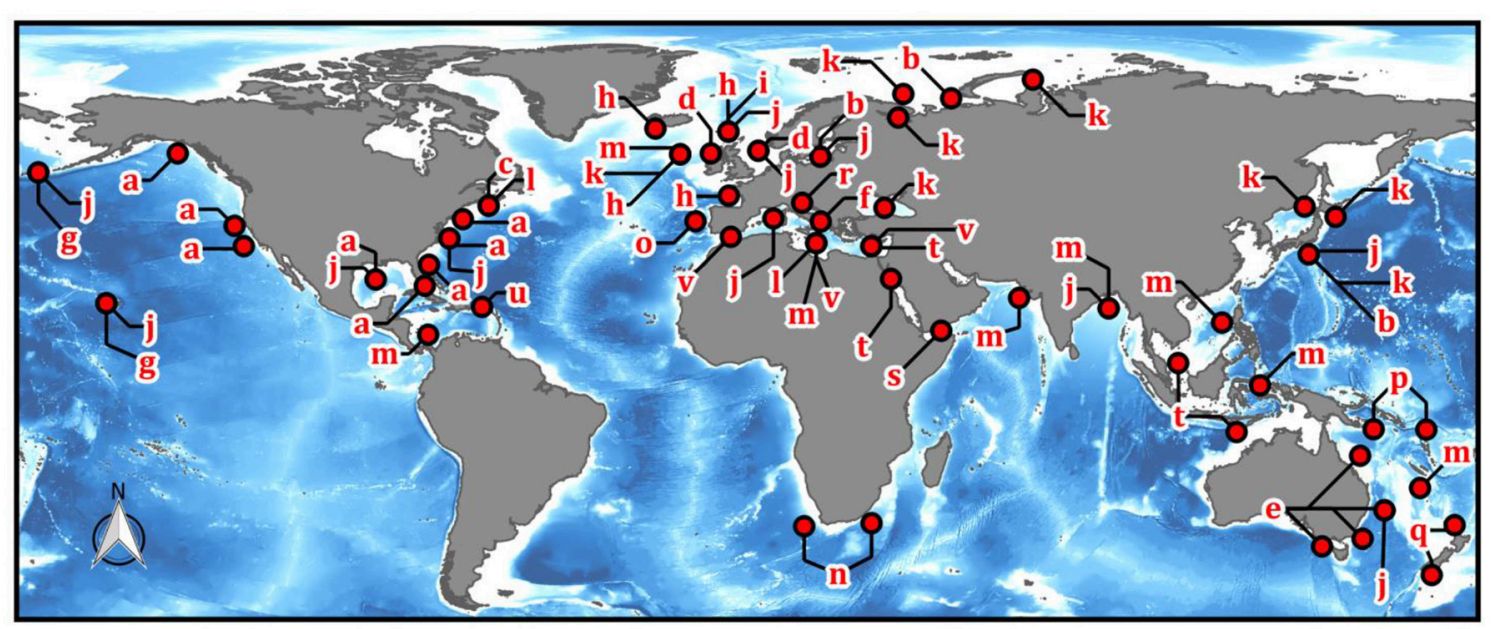

FIGURE 3 | Global distribution of documented marine sites with munitions present (includes conventional weapons, chemical weapons, and UXO). Letters refer to literature references: a, MEDEA (1997) and Bohaty (2009); b, MEDEA (1997); c, Ampleman et al. (2004); d, Missiaen and Henriet (2002); e, Plunkett (2003); f, Amato et al. (2006a,b); g, Bearden (2007); h, Nixon (2009); I, HELCOM (1995); j, Brankowitz (1989); k, James Martin Center for Nonproliferation Studies (2017); I, Bull (2005a,b); m, US ARMY (2001); n, Godschalk and Ferreira (1998); o, Thiel (2003); p, Francis and Alama (2011); q, Royal New Zealand Navy (2015); r, Obhodas et al. (2010) and Valkovic et al. (2009); s, Nadim et al. (2008) and National Geospatial-Intelligence Agency (2017); t, Landmine Action (2005); u, Porter et al. (2011); v, UNEP/MAP (2009). Note that the map resolution is coarser than the number of actual munitions dumps; for example, the OSPAR report by Nixon (2009) (letter h) contains 148 individual munitions dumpsites. (Image drawn using QGIS, with data from: The GEBCO_2014 Grid, version 20150318, Wessel and Smith, 2017).

(Samuel and Herbert, 2007; Grabowski et al., 2018). Multibeam echo sounders provide higher geospatial accuracy and have been used to supplement sidescan data to produce exceptionally high resolution images of munition-containing shipwrecks (Sæbø et al., 2015). Towed or remote/autonomously-operated vehiclemounted magnetometers can provide supporting information by identifying metal objects on and immediately below the seafloor (Asahina et al., 2009; Schultz et al., 2016; Grabowski et al., 2018). Sub-bottom profilers identify dense objects buried in the seafloor (Chabert, 2016; Grabowski et al., 2018), but are also non-specific for munitions and may provide false positives. Multiple techniques applied in combination improve confidence in detection and identification (Missiaen and Feller, 2008). Modern technological advances in instrumentation have improved both capability and cost (Williams, 2016), but available techniques remain limited in terms of spatial coverage and widespread application.

\section{CORROSION OF MUNITIONS HOUSINGS AND RELEASE OF EXPLOSIVES}

Munitions exposed to seawater for long periods of time experience extensive corrosion, but constraining corrosion processes in the heterogeneous environments affecting undersea munitions is exceptionally difficult (MEDEA, 1997). Consequently, there is little quantitative evaluation available on corrosion of undersea munitions. Salinity, temperature, and pressure are all likely to play an important role in corrosion rates (Rossland et al., 2010; MacLeod, 2016; Jurczak and Fabisiak, 2017). In contrast, Granbom (1994) remarked that these parameters have little effect on corrosion rates, although no data were provided. Similar anecdotal reports from 1996 suggested that chemical munitions dumped in the Baltic following WWII have corroded by between 70 and 100\% (Lisichkin, 1996; Surikov, 1996). A number of reports have noted a Russian estimate that corrosion will lead to maximum chemical release rates in the early twenty first century from submerged munitions in the Baltic Sea (Granbom, 1994; Malyshev, 1996; Glasby, 1997). One study on WWII-era shipwrecks in Micronesia measured corrosion rates on the order of $0.1 \mathrm{~mm} \mathrm{y}^{-1}$ (MacLeod, 2016), suggesting that corrosion depths after 70 years may be nearly $1 \mathrm{~cm}$.

One study in Hawaii (US) examined nearly 2000 submerged WWII-era munitions, and found that some $95 \%$ had a significant to severe degree of corrosion (Silva and Chock, 2016). Similarly, a Danish report indicated that munitions in the Bornholm Basin are "completely corroded" (Sanderson and Fauser, 2015). In the Adriatic Sea, chemical munitions have been observed on the seafloor with corrosion extensive enough that the munition material was exposed or spread on the surrounding sediment surface (Amato et al., 2006a). Many of the munition walls were breached, with contents exposed to seawater, and unusual corrosion features such as secondary concretions were observed (Silva and Chock, 2016). Munition shells recovered from the seafloor in another study showed that these secondary concretions include $\mathrm{Fe}$ hydroxychloride, Fe-(hydr)oxide, Fe carbonate, and Ca carbonate (George et al., 2015; Li et al., 2016). The use of different metal types in munition bodies, such as steel casing and copper driving band, can lead to accelerated galvanic corrosion, although authigenic mineral precipitation and biological overgrowth may slow corrosion rates (George et al., 2015; Srinivasan and Hihara, 2016; Jurczak and Fabisiak, 2017). On the other hand, biological encrustations may 
increase metal corrosion by increasing the oxygen flux to the surface (MacLeod, 2016). Corrosion also appears to be inhibited when munitions are buried in sediments or exposed to anoxic conditions (Wang et al., 2011; George et al., 2015).

Perhaps unsurprisingly, the release of munition compounds (MC) from munitions in aquatic environments is greater for munitions exposed in the water column compared with those buried in sediments (Wang et al., 2013). Release rates also increase with increases in munition casing breach size (i.e., exposure area of solid explosive material) and with increasing current and water mixing rates (Wang et al., 2013). It has been suggested that corrosion rates increase greatly with current speed or stirring (Granbom, 1994; Overfield and Symons, 2009), suggesting that high energy environments such as shallow coastal waters may promote both exposure and dissolution of explosive material. Modeled release rates are consistent with experimental measurements of explosives dissolution under variable mixing conditions (Lynch, 2002; Lynch et al., 2002).

Modeling efforts suggest that TNT release from submerged munitions is likely to be slow, with predicted concentrations in water near the munitions only on the order of nanograms per liter (Wang et al., 2013). This is consistent with mesocosm experiments showing slow dissolution and rapid dilution of dissolved MC in water overlying exposed munition fragments under low flow conditions (Rosen and Lotufo, 2010). Munition material exposed to seawater in situ for 3 years showed minor visual evidence of dissolution (Ek et al., 2006), surprising, as the authors note, given that TNT solubility is on the order of $10^{1}-10^{2}$ $\mathrm{mg} \mathrm{L}^{-1}$ (i.e., tens to hundreds of milligrams $\mathrm{MC}$ per liter water; see below).

\section{DISSOLUTION OF MUNITION COMPOUNDS}

Some basic physicochemical parameters for TNT, RDX, and HMX are shown in Table 1. In general, these data illustrate that the MCs of interest exhibit very low volatility and are not

TABLE 1 | Physicochemical properties of TNT, RDX, and HMX.

\begin{tabular}{|c|c|c|c|}
\hline & TNT & RDX & HMX \\
\hline CAS number & 118-96-7 & $121-82-4$ & $2691-41-0$ \\
\hline Chemical formula & $\mathrm{C}_{7} \mathrm{H}_{5} \mathrm{~N}_{3} \mathrm{O}_{6}$ & $\mathrm{C}_{3} \mathrm{H}_{6} \mathrm{~N}_{6} \mathrm{O}_{6}$ & $\mathrm{C}_{4} \mathrm{H}_{8} \mathrm{~N}_{8} \mathrm{O}_{8}$ \\
\hline $\begin{array}{l}\text { Molecular weight (g } \\
\mathrm{mol}^{-1} \text { ) }\end{array}$ & 227.13 & 222.26 & 296.16 \\
\hline Specific gravity & $1.5-1.6$ & 1.82 & 1.96 \\
\hline Melting point $\left({ }^{\circ} \mathrm{C}\right)$ & $80-82$ & 204-205 & $276-286$ \\
\hline $\begin{array}{l}\text { Vapor pressure (atm @ } \\
20^{\circ} \mathrm{C} \text { ) }\end{array}$ & $7.2-262 \times 10^{-9}$ & $5.3 \times 10^{-12}$ & $4.3 \times 10^{-17}$ \\
\hline 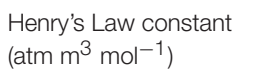 & $1.1-45.7 \times 10^{-8}$ & $0.0196-63 \times 10^{-9}$ & $2.6 \times 10^{-15}$ \\
\hline $\begin{array}{l}\text { Octanol-water partition } \\
\text { coefficient (log Kow) }\end{array}$ & 1.6 & 0.9 & 0.17 \\
\hline
\end{tabular}

References: Lotufo et al. (2017), Juhasz and Naidu (2007), Monteil-Rivera et al. (2009), and Brannon and Pennington (2002). strongly hydrophobic and therefore unlikely to sorb strongly to particle surfaces. In contrast, dissolution of these compounds from solid explosives shows marked dependence on factors such as temperature, and environmental variation is therefore likely to influence the dissolution and release of MC from solid explosives. Dissolution of MC from explosive solids represents the initial controlling factor for release into the environment and exposure to ecological receptors.

\section{Solubility}

The trend of TNT solubility with temperature is consistent across freshwater studies, increasing from approximately $50 \mathrm{mg} \mathrm{L}^{-1}$ at $2^{\circ} \mathrm{C}$ to $100 \mathrm{mg} \mathrm{L}^{-1}$ at $25^{\circ} \mathrm{C}$, and increasing rapidly at higher temperatures (Figure 4A; Table 2). However, there remains substantial variability in measured solubility at temperatures relevant to the marine environment. For example, at $20^{\circ} \mathrm{C}$, reported solubility for TNT varies between 70 and $120 \mathrm{mg} \mathrm{L}^{-1}$ among different studies. There appears to be little effect of $\mathrm{pH}$ on TNT dissolution within the environmentally-relevant temperature range (Ro et al., 1996; Lynch et al., 2001). At high $\mathrm{pH}(>9)$ and temperature above $40^{\circ} \mathrm{C}$, dissolution appears to be suppressed, although this may be related to chemical decomposition or transformation processes (Ro et al., 1996).

Solubility curves for RDX and HMX also show an exponential increase with temperature, although less data is available than for TNT (Figures 4B,C). RDX and HMX show 3- and 60-fold lower solubility than TNT, respectively, although the relative difference decreases as temperature increases (Figure 5). For example, the relative difference in solubility between TNT and HMX decreases by nearly a factor of two between 0 and $25^{\circ} \mathrm{C}$. This suggests that the spread of different $\mathrm{MC}$ from submerged munitions will vary in part due to differential dissolution of components within explosive mixtures, as has been observed in terrestrial systems (Efroymson et al., 2009).

To our knowledge, only two reports have examined the solubility of MC in seawater compared with fresh water (Luning Prak and O'Sullivan, 2006, 2007). In general, MC are moderately less soluble ( $\sim 20 \%$ lower) in seawater than fresh water (e.g., TNT, Figure 4A), although no effect is evident in tap or fresh water compared with deionized water. Addition of organic substrates such as molasses in laboratory experiments appears to enhance the solubility of MC (Fuller et al., 2004). Release of adsorbed TNT is similarly enhanced in the presence of surfactants (Boopathy and Manning, 1999), suggesting that MC solubility may be elevated in systems with high concentrations of dissolved organic matter.

\section{Dissolution Kinetics}

A wide range of rates has been reported for MC dissolution from munition solids, with the greatest difference apparently due to stirring or mixing speed (Table 3). The 1,000-fold variation in dissolution rate with mixing speed far exceeds the slight reduction of dissolution rate in seawater compared with fresh water (Brannon et al., 2005). This implies that munition dissolution in seawater may depend most strongly on physical processes regulating transport from the solid surface, and release will therefore vary among sites (e.g., depending on waves, 


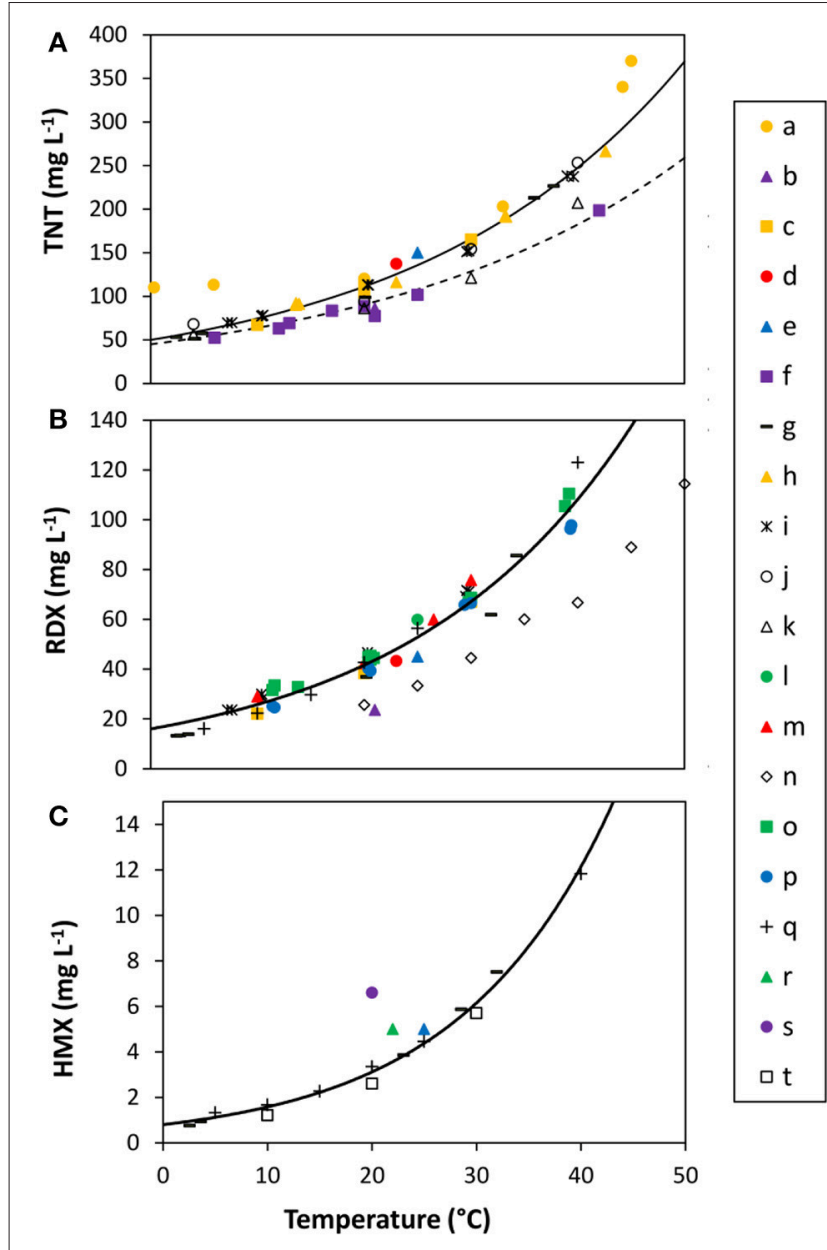

FIGURE 4 | MC solubility as a function of temperature. (A) TNT, (B) RDX, (C) HMX. Solid (freshwater) and dashed (seawater) lines represent visual fits to the data, omitting apparent outliers, according to the exponential model used by Bier et al. (1999) (Solubility $=a^{*} e^{b T}$; coefficients are given in Table 2). Letters identify data sources: a, Taylor and Rinkenbach (1923); b, Hale et al. (1979); c, Spanggord et al. (1983); d, Leggett (1985); e, Rosenblatt et al. (1989); f, Ro et al. (1996); g, Lynch et al. (2001); h, Phelan and Barnett (2001); i, (Composition B, tap water) (Phelan et al., 2002); j, (freshwater) (Luning Prak and O'Sullivan, 2006); k, (seawater) (Luning Prak and O'Sullivan, 2006); I, Banerjee (1980); m, Sikka et al. (1980); n, Bier et al. (1999); o, (pure RDX deionized water) (Phelan et al., 2002); p, (pure RDX, tap water) (Phelan et al., 2002); q, Monteil-Rivera et al. (2004); r, Glover and Hoffsommer (1973); s, Spanggord et al. (1982); t, McLellan et al. (1988).

currents, and tides). This is consistent with the results of Porter et al. (2011) who showed that dissolved TNT was saturated within breached munitions, but concentrations declined by over three orders-of-magnitude within $10 \mathrm{~cm}$ of the munition surface.

The dissolution rate increases rapidly with temperature, with a 4 -fold increase from $10^{\circ} \mathrm{C}$ to $30^{\circ} \mathrm{C}$ (Table 3). From the measured dissolution rates and reported solubilities (Figure 4), MC concentrations would be expected to reach saturated concentrations within a few days in a well-stirred, enclosed system. However, under low flow, poorly mixed conditions (e.g.,
TABLE 2 | Coefficients for exponential fits of MC solubility as a function of temperature (Figure 4).

\begin{tabular}{lcc}
\hline MC & \multicolumn{2}{c}{ Coefficient } \\
\cline { 2 - 3 } & $\mathbf{a}$ & b \\
\hline TNT (FW) & 50 & 0.04 \\
TNT (SW) & 45 & 0.035 \\
RDX & 16 & 0.0478 \\
HMX & 0.8 & 0.068
\end{tabular}

"TNT (SW)" refers to the solubility trend measured in seawater (Luning Prak and O'Sullivan, 2006).

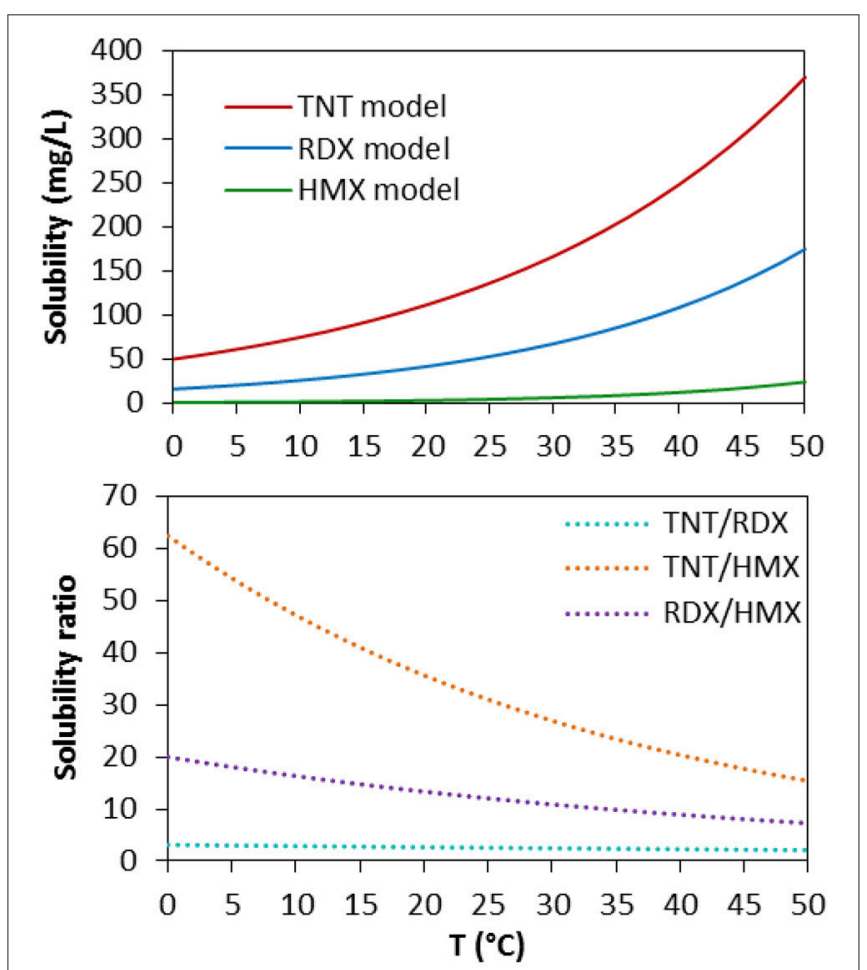

FIGURE 5 | (A) Solubility of TNT, RDX, and HMX as a function of temperature according to the exponential model (Bier et al., 1999) (Table 2). (B) Relative solubility of TNT, RDX, and HMX as a function of temperature.

Thiboutot et al., 1998), MC dissolution may require weeks to months to reach saturation.

Dissolution of MC from solid explosives also depends on formulation, with less-soluble components such as RDX tending to suppress dissolution rates of more soluble components such as TNT (Lynch et al., 2001; Lever et al., 2005). The explosive formulation also determines the relative exposed surface of specific MC. For example, surface area-normalized RDX dissolution was twice as fast from C4 (82\% RDX, 9\% HMX, 9\% plasticizers) than from Composition B (54\% RDX, 6\% HMX, $40 \%$ TNT) (Morley et al., 2006). However, explosive mixtures do not appear to impact the saturation concentration of the individual MC (e.g., Phelan et al., 2002, Figure 4B). 
TABLE 3 | Dissolution rates of TNT, RDX, and HMX from pure and composite explosives.

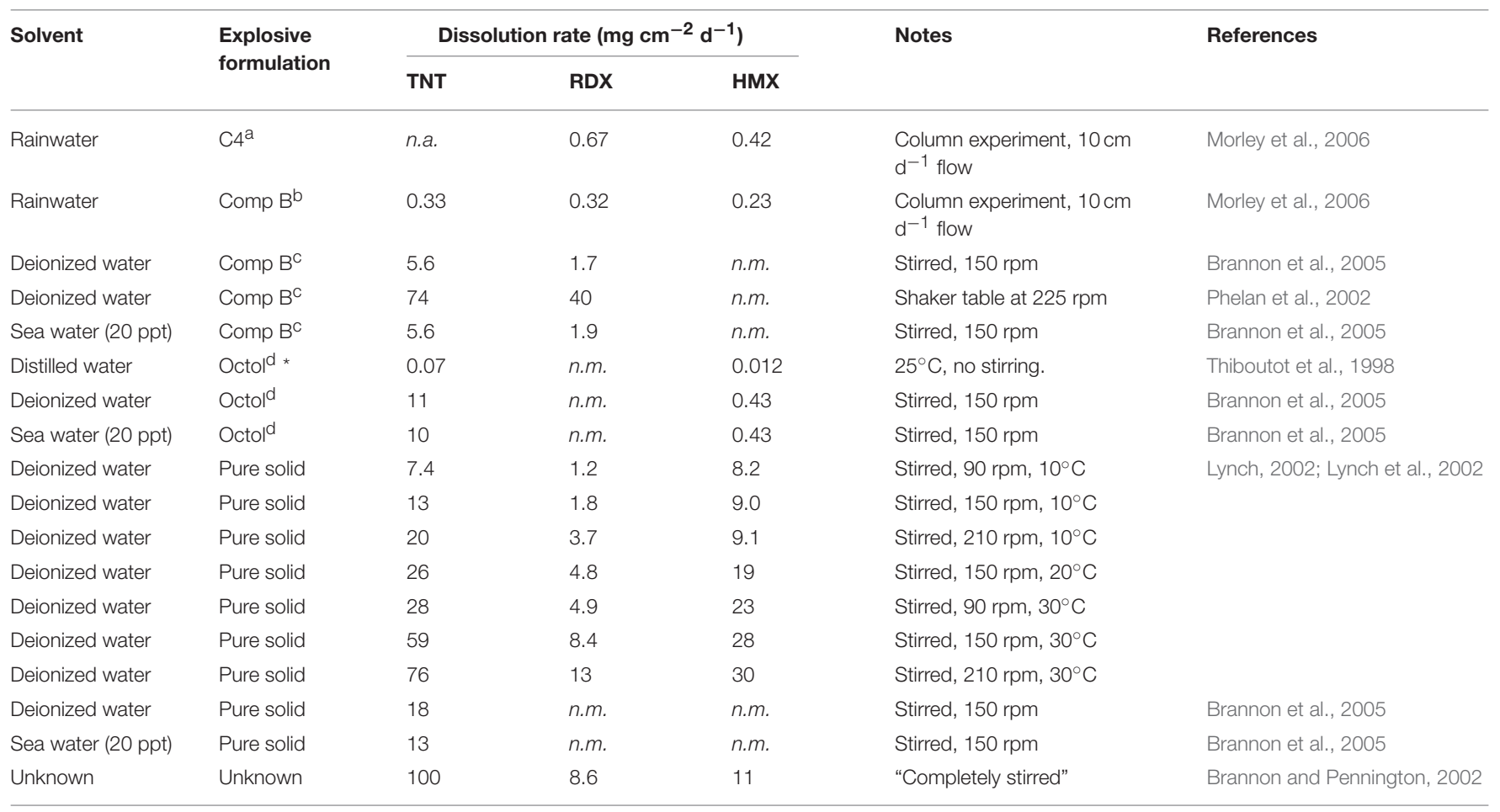

a $82 \%$ RDX, 9\% HMX, 9\% plasticizers.

${ }^{b} 54 \%$ RDX, 6\% HMX, 40\% TNT.

${ }^{c} 60 \%$ RDX, $40 \%$ TNT.

${ }^{d} 70 \%$ HMX, 30\% TNT.

n.a., not applicable.

n.m., not measured.

${ }^{\star}$ Surface area calculated using Octol density $\left(1.81 \mathrm{~g} \mathrm{~cm}^{-3}\right)$ (Baytos, 1980) and assuming spherical geometry.

\section{FIELD STUDIES AND DETECTION}

\section{Organic MC}

Several different analytical methods have been reported for detection of MCs in environmental samples (Barshick and Griest, 1998; Bromage et al., 2007; Badjagbo and Sauvé, 2012a; Xu et al., 2014; Rapp-Wright et al., 2017), but vary in their specificity, simplicity, and detection limits. The most widely used method of dissolved MC analysis relies on solvent extraction, separation by HPLC, and UV-VIS detection to achieve detection limits in the $\mu \mathrm{g} \mathrm{L}^{-1}$ range (US EPA Method 8330) (EPA, U. S., 2007). However, UV-VIS detection does not allow definitive compound identification or analysis of poor light-absorbing MCs such as nitroglycerine or [3-Nitrooxy-2,2-bis(nitroxymethyl)propyl] nitrate (PETN). In addition, mobile phase conditions can result in poor peak separation and shifts in retention time, complicating compound identification. In addition, colored organic matter is abundant in seawater, and can interfere with detection by UVVIS spectrometry. More recently, atmospheric pressure chemical ionization (APCI) (Badjagbo and Sauvé, 2012a; Xu et al., 2014; Rapp-Wright et al., 2017), electrospray ionization (ESI) (Gapeev et al., 2003), and electron impact ionization (EI) (Yinon, 1982; Berg et al., 2007) mass spectrometry (MS) (Badjagbo and Sauvé, 2012b) have been successfully applied for the analysis of
MCs, with greatly enhanced sensitivities and specificity. To our knowledge, these methods have not yet been applied to studies of $\mathrm{MC}$ distribution and behavior in the marine environment.

A number of studies have attempted to measure MCs in seawater, sediments, and organisms, and the results have been rather variable from site to site (Lotufo et al., 2017). The variability of detections as a function of distance from the target is likely due to the filamentous nature of the plumes emanating from the target (Rodacy et al., 2001; Camilli et al., 2009). One of the earliest reports of positive detection found low $\mu \mathrm{g} \mathrm{kg}^{-1}$ levels of TNT and DNT in sediments near intact, live munitions in Halifax Harbor, Canada (Darrach et al., 1998). Another study from Halifax (Rodacy et al., 2001) used solid-phase micro extraction to sample MC in seawater near submerged munitions, and found trace levels of DNB, DNT, and ADNT in the dissolved phase $\left(<1 \mu \mathrm{g} \mathrm{L}^{-1}\right)$. This study also measured $10^{1}-10^{2} \mu \mathrm{g}$ $\mathrm{kg}^{-1}$ levels of TNT, TNB, DNB, DNT, and ADNT in sediments collected near munitions. In two later studies from Halifax, MC were detected following detonation events (BIP), but not at historical dumpsites (Ampleman et al., 2004).

Seafloor incubations of purposely halved artillery shells (i.e., freshly exposed TNT and RDX) in one Swedish study did not result in measurable TNT or degradation products in the water column or adjacent sediments (Ek et al., 2006). Another 
study in the Baltic Sea detected TNT and ADNT in sediment samples near a munitions dumpsite (Pfeiffer, 2012b). A study at Ordnance Reef, Hawaii, USA, found DNT of probable munition origin in 5 of 47 sediment samples, but it was unclear if the compounds could have come from other, industrial sources (Decarlo et al., 2007). No MC were detected in fish at Ordnance Reef (Decarlo et al., 2007). Mustard agent compounds were detected in sediments near chemical munition dumpsites in Skaggerak basin (Granbom, 1996), indicating the potential for shell breaching and chemical release.

One of the most extensive studies on MC distribution at undersea sites was performed at Vieques Island, Puerto Rico (Porter et al., 2011). The authors measured TNT concentrations near maximum solubility within breached munitions (up to $86 \mathrm{mg} \mathrm{L}^{-1}$ ), and low concentrations (low $\mu \mathrm{g} \mathrm{L}^{-1}$ ) in the nearby water column. A number of other munition-derived compounds were also detected, including di- and mono-nitrotoluenes, nitrobenzenes, and RDX. Munition compounds were detected in many, but not all, sediments and biota (corals, feather duster worms, and sea urchins) near munitions. In contrast, no MC were detected in water, sediment, or organism tissue in other studies at heavily contaminated sites in Vieques Island (NOAA and Ridolfi, 2006; CH2M HILL, 2015). Similarly, HMX was not observed in porewater or sediment samples at naval weapons training sites in Vieques (Simmons et al., 2007).

It is important to bear in mind that many of the organic $\mathrm{MC}$ and their transformation products are strongly bound in biotic tissues and during sorption, to the extent that solventextraction and identification are hampered (Pennington et al., 1995; Achtnich et al., 1999; Ownby et al., 2005; Ballentine et al., 2015; Ariyarathna et al., 2016). Procedures using multi-step extractions including acid and base reagents have achieved more complete recovery of MCs (Thorne and Leggett, 1997; Belden et al., 2011; Lotufo et al., 2016). This suggests that lack of MC detection in previous studies may be a methodological artifact or lack of sensitivity, and not definitive of MC absence in sediments or biota.

\section{Metals}

Terrestrial military ranges show clear contamination of metals from weapons firing (e.g., Stauffer et al., 2017), but most studies of metal release from undersea munitions show little evidence for contamination above background levels (e.g., Decarlo et al., 2007; Garcia et al., 2009). One study in Halifax, Canada, found high levels of metals including $\mathrm{Pb}$ in sediments near munitions dumpsites, but it was not clear that the contamination was derived from the munitions (Ampleman et al., 2004). Valkovic et al. (2009) found trends suggesting that sediment $\mathrm{Cr}$ and $\mathrm{Ni}$ content was elevated in the vicinity of a torpedo in coastal waters of Croatia. Porter et al. (2011) observed elevated levels of Cr in sediments near submerged munitions.

Peaks in $\mathrm{Hg}$ deposition in North and South America and western Europe occurred around 1940, coinciding with the period of maximum production during WWII (Biester et al., 2002; Schuster et al., 2002; Corella et al., 2017). Mercury contamination of sediments near munitions dumpsites in the Baltic Sea is generally not elevated relative to other sites within the region (Gebka et al., 2016). Elevated levels of $\mathrm{Hg}$ in fish near munitions dumpsites have been attributed to mercury fulminate (Della Torre et al., 2010), although a definitive link was not shown. Mercury records in corals from the South China Sea show peaks in concentration that appear to coincide with regional wars (Sun et al., 2016). However, it is unclear if a munition $\mathrm{Hg}$ source is substantial enough to sufficiently elevate concentrations in seawater (C. Lamborg, as cited by Monahan, 2016).

\section{TRANSFORMATION AND MINERALIZATION}

Several excellent comprehensive reviews are available that describe environmental pathways for MC degradation (Spain et al., 2000; Monteil-Rivera et al., 2009; Kalderis et al., 2011; Szecsody et al., 2014). Some of the known major pathways are described here to illustrate the transformation and degradation products that are likely to occur under environmental conditions at marine munitions sites (Figures 6-9). Because photolysis and Fenton reaction mechanisms tend to produce different reaction

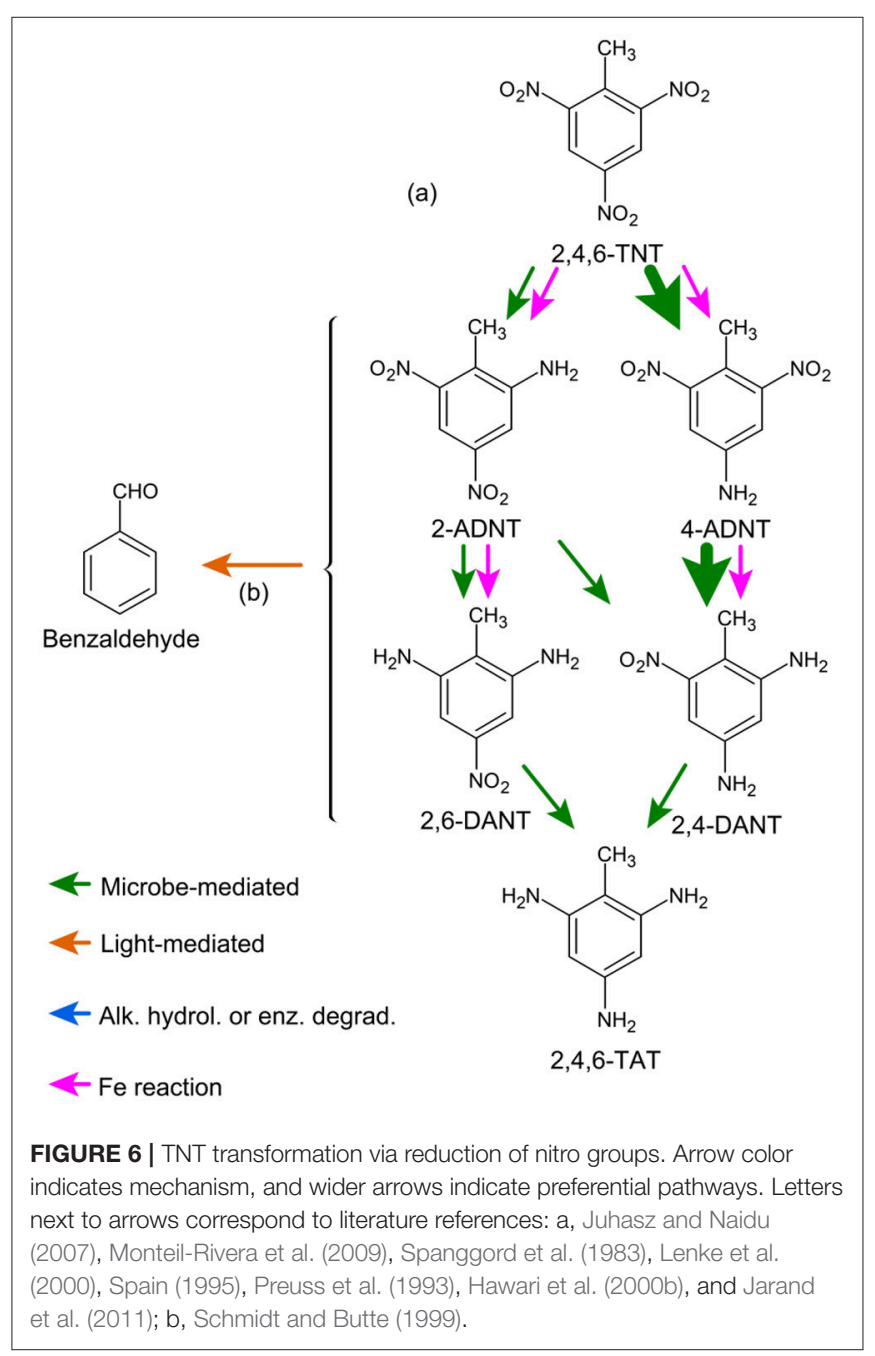




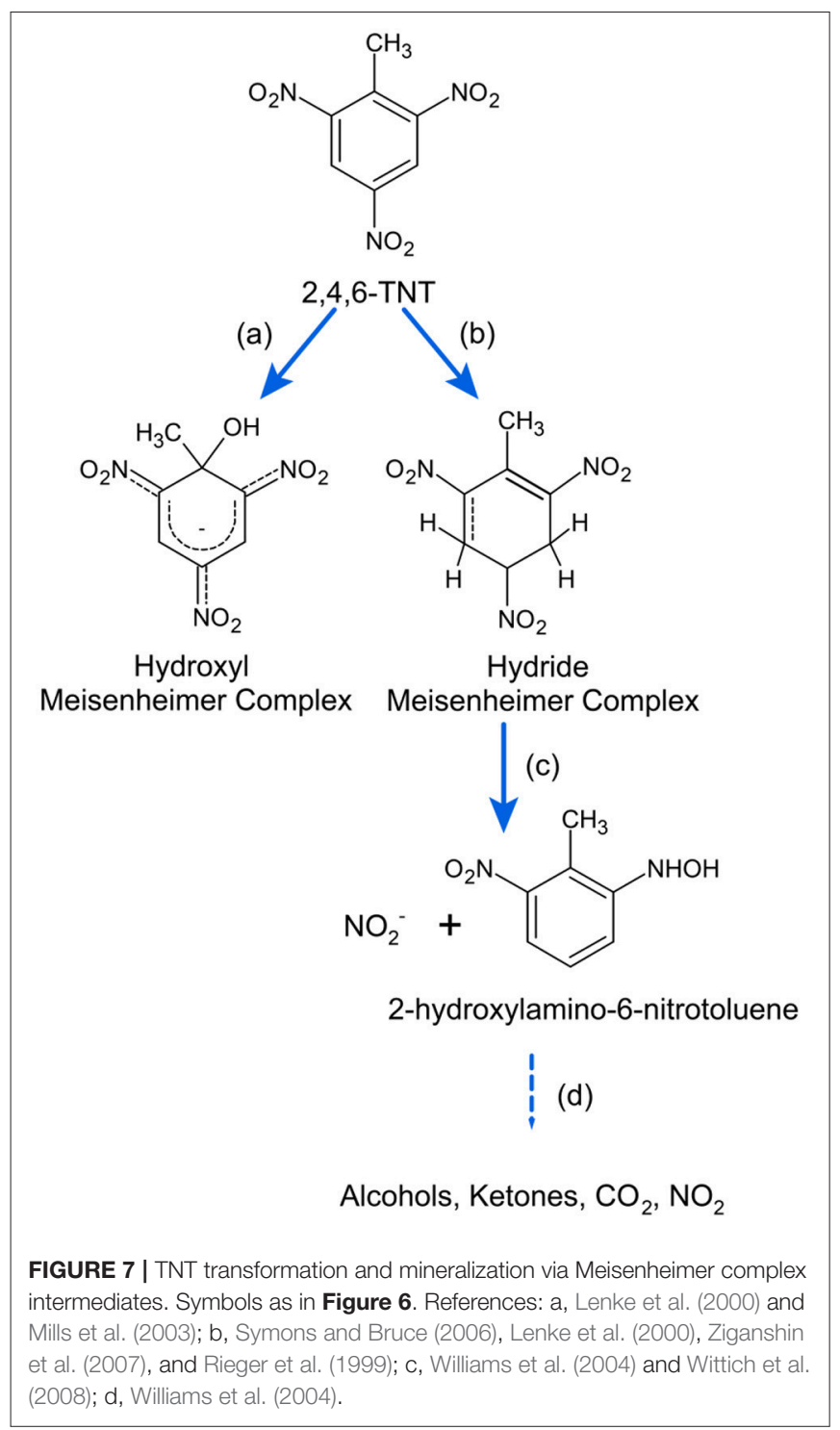

products from the primary biotic pathways, they are discussed separately below. The geochemical behavior of different reaction products determines their persistence, and indeed their ability to be detected using current analytical methods, in water, sediments, and biota.

Reports of TNT degradation conflict on whether TNT is microbially mineralized to $\mathrm{CO}_{2}$ and inorganic $\mathrm{N}$, or if it is simply transformed primarily to amino derivatives (Figure 6) (Hawari et al., 2000a). In contrast, RDX and HMX can be transformed to nitroso forms, but also readily undergo ring cleavage and mineralization (Figure 9) (Halasz and Hawari, 2011). Microbial transformation of TNT in terrestrial systems appears to occur primarily via reduction of the nitro groups, but does not lead to mineralization (Best et al., 1999; Wijker et al., 2013). Zheng et al. (2009) showed that TNT, RDX, and HMX all degraded to amino or nitroso derivatives when streamwater permeated through anoxic riverbank sediments, but only TNT degraded under oxic conditions. Thus, geohydrologic controls that drive seawater circulation through permeable sediments (e.g., Santos et al., 2012) may promote MC degradation in coastal marine systems. Mineralization of TNT and RDX has been reported under remediation conditions by photolysis (Yardin and Chiron, 2006) and alkaline hydrolysis (Felt et al., 2001).

Some enzymes act not only as reductases, but can also react with TNT by hydride or hydroxyl addition to form Meisenheimer complexes with subsequent release of nitrite and ring cleavage (Figure 7) (Lenke et al., 2000; Williams et al., 2004; Symons and Bruce, 2006). Hydride addition to TNT has been shown for a marine yeast (Ziganshin et al., 2007). Reaction products may also undergo condensation reaction to form stable diarylamines (Wittich et al., 2008).

\section{TNT Transformation}

TNT transformation generally occurs via sequential reduction of the nitro groups to amino forms (Figure 6), and can occur by both biotic and abiotic mechanisms (Spain, 1995; Brannon and Pennington, 2002). The mono- and di-amino forms (ADNT and DANT, respectively) are produced by both bacteria and fungi via aerobic and anaerobic pathways (see detailed reviews in Spain, 1995; Juhasz and Naidu, 2007; Monteil-Rivera et al., 2009). Triaminotoluene (TAT) is formed only under strict anaerobic conditions (e.g., Preuss et al., 1993), although it tends to be removed rapidly from solution and is not persistent (see below).

There is extensive evidence for regioselective reduction of TNT nitro moieties, with the para form dominating over the ortho form to a variable degree depending on the relative importance of abiotic and biotic pathways (Barrows et al., 1997). In one study conducted with sludge incubation, concentrations of 4-ADNT and 2,4-DANT reached two- and ten-fold higher, respectively, than the 2-ADNT and 2,6-DANT forms (Hawari et al., 1998). Similar preferential formation of 4-ADNT has been shown in other soil and plant systems (Harvey et al., 1990). In aerobic sediment incubations, TNT removal was rapid, with little TNT sorption and virtually exclusive formation of the 4-ADNT and 2,4-DANT metabolites (Elovitz and Weber, 1999). Under anaerobic conditions, degradation is more rapid [minutes time scale (Preuss et al., 1993; Elovitz and Weber, 1999)], and appears to rapidly progress to the 2,4-DANT product (Elovitz and Weber, 1999).

Rates of nitro group reduction under aerobic conditions decrease sequentially (Elovitz and Weber, 1999), and TNT degradation products may be removed from solution by sorption and binding to solid phases (see below) before progressing to the terminal TAT product. This also implies a greater immobilization of the ADNT forms compared with DANT. TAT is not stable in solution, undergoing hydrolysis to azo- (under anoxic conditions) and hydroxy- (under oxic conditions) intermediate forms, and eventually polymerizing and precipitating (Hawari et al., 1998). Unknown products formed under anoxic conditions appear to be derived from a TAT precursor (Elovitz and Weber, 1999), consistent with formation of TAT hydrolysis azo- products (Hawari et al., 1998). 
<smiles>Cc1c([N+](=O)[O-])cc([N+](=O)[O-])cc1[N+](=O)[O-]</smiles>

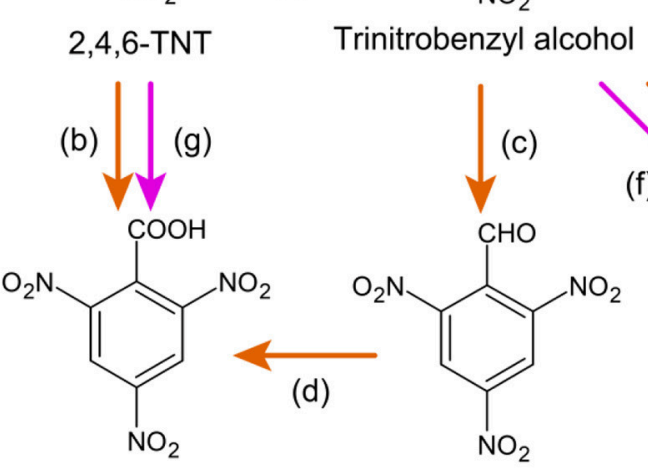

Trinitrobenzoic acid Trinitrobenzaldehyde<smiles>CC(C)(C)OC(=O)OCCc1c(O)cc(O)cc1O</smiles>

Trihydroxybenzene<smiles>ICI</smiles>

Oxalic acid

FIGURE 8 | TNT transformation and mineralization via photo- and Fenton- reaction. Symbols as in Figure 6. References: a, Spanggord et al. (1983), Godejohann et al. (1998), Luning Prak et al. (2017), and Burlinson et al. (1979a); b, Luning Prak et al. (2017) and Burlinson et al. (1979a); c, Luning Prak et al. (2017); d, Godejohann et al. (1998), Kaplan et al. (1975), and Schmelling and Gray (1995); e, Spanggord et al. (1983) and Godejohann et al. (1998); f, Jarand et al. (2011) and Hess et al. (2003); g, Hess et al. (2003); h, Hess et al. (2003), Liou et al. (2003), and Li et al. (1998); i, Spanggord et al. (1983) and Godejohann et al. (1998).

\section{TNT Mineralization}

TNT mineralization in terrestrial systems occurs very slowly, with a reported half-life up to several decades (Wijker et al., 2013). Evolution of $\mathrm{CO}_{2}$ from ${ }^{14} \mathrm{C}$-labeled $\mathrm{TNT}$ has been observed in biotic soil incubations, but rates were slow and indicated half-lives of 4-10 years (Cataldo et al., 1989). Mineralization of TNT was also very low in wetland experiments (Best et al., 1999). Most of the TNT transformation (>80\%) in these incubations was accounted for by ADNT formation, although approximately $50 \%$ of the label was in the nonextractable pool after 2 months. Interestingly, the authors observed ADNT formation in both biotic and radiation-sterilized treatments, although to a lesser degree in the latter.

Degradation experiments using seawater from the North Sea also showed slow mineralization rates, with half-life on the order of 5 years (Harrison and Vane, 2010). In contrast, TNT, RDX, and HMX degradation in some coastal waters, especially fresh-saline mixing zones, may occur much more rapidly, on the order of days to weeks (Montgomery et al., 2014). Degradation rates in sediments tend to be faster than those in water (Harrison and Vane, 2010). Montgomery et al. (2011a) proposed that the mineralization observed in marine systems, but not terrestrial systems, may be why MC are rarely observed in marine sediments.

In marine mesocosm experiments using ${ }^{15} \mathrm{~N}$-TNT, Smith et al. (2015a) showed a rapid decrease in dissolved TNT, with most of the labeled $\mathrm{N}$ either in sediments or in an undetected "missing" pool (maximum of $\sim 20 \%$ and $>80 \%$, respectively, at different time points). A small fraction of the labeled $\mathrm{N}$ did appear either in macrobiota biomass (approximately 15\%), or as 


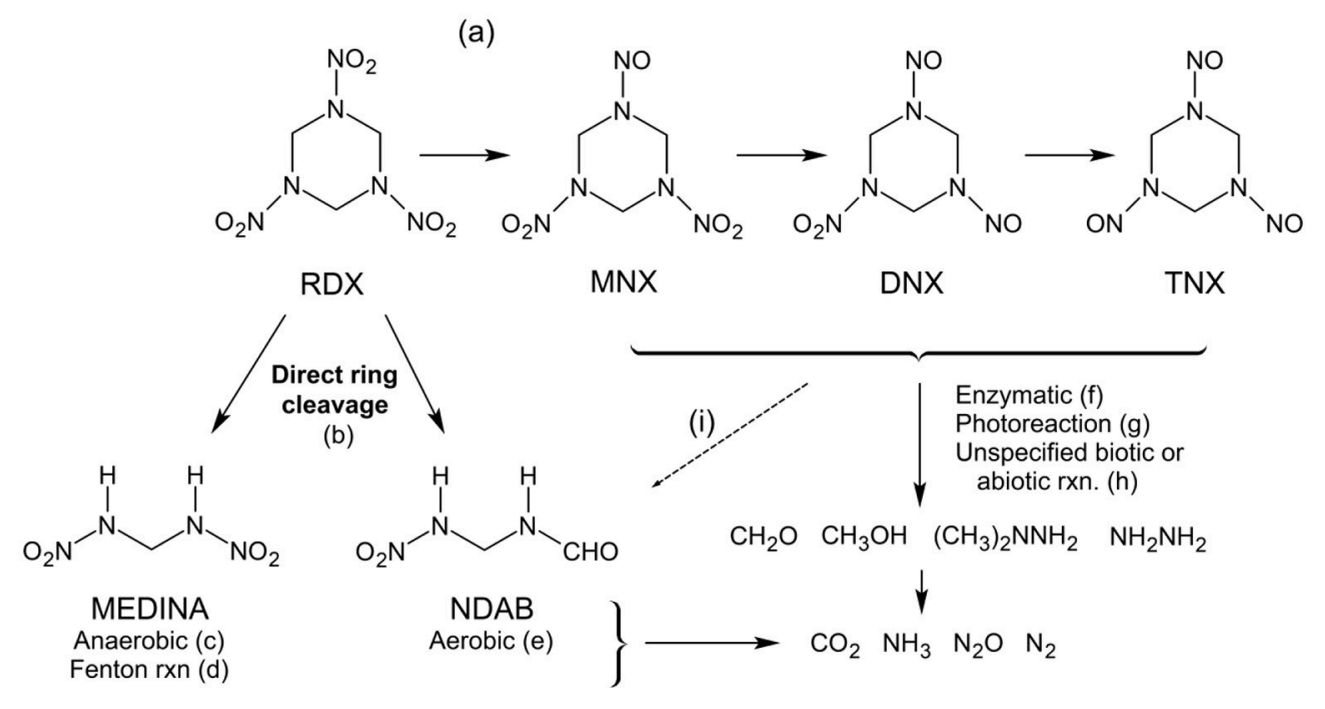

FIGURE 9 | RDX transformation and mineralization reaction pathways. HMX degradation follows identical pathways, and is not shown here for simplicity. References: a, Juhasz and Naidu (2007), McCormick et al. (1981), Van Aken et al. (2004), Hawari et al. (2001), and Sheremata et al. (2001); b, Ariyarathna et al. (2016), Halasz and Hawari (2011), Smith et al. (2015b), Liou et al. (2003), and Hawari et al. (2001); c, McCormick et al. (1981), Jackson et al. (2007), and Hawari et al. (2000c); d, Liou et al. (2003), Oh et al. (2003), and Zoh and Stenstrom (2002); e, Jackson et al. (2007) and Monteil-Rivera et al. (2008); f, Van Aken et al. (2004); g, Van Aken et al. (2004) and Bose et al. (1998); h, Ariyarathna et al. (2016), Hawari et al. (2000c), Monteil-Rivera et al. (2008), and Zhao et al. (2004); i, McCormick et al. (1981).

dissolved, inorganic remineralization products $(\sim 7 \%)$, consistent with the ability of some microbes to use TNT-nitrogen for growth (Wittich et al., 2009). The only TNT transformation product detected in the mesocosms was ADNT, with slight preferential formation of the 4A-DNT isomer (Smith et al., 2015a). These researchers hypothesized that further deamination of ADNT led to unidentified products comprising the "missing" pool.

Montgomery et al. (2011a) hypothesized that because marine systems tend to be nitrogen-limited, microbial mineralization of nitroaromatics is more likely than in P-limited terrestrial or aquifer environments. They studied a range of estuarine and coastal marine sites in the USA (Kahana Bay, Chesapeake Bay, Delaware Bay, and San Francisco Bay), and report that although TNT mineralization in sediments was variably observed in space and time, it was measurable at least once at virtually all sites (Walker et al., 2006).

A relatively small fraction of TNT added to water and sediment slurries is mineralized (generally $<10 \%$, but up to $30 \%$ ), but $80-99 \%$ of the mineralized TNT-carbon is incorporated into bacterial biomass (Montgomery et al., 2011b, and references therein). This suggests that most of the TNT metabolism occurs via assimilation for biomass production rather than solely as an energy source (Montgomery et al., 2013). Mineralization of N from TNT and RDX has also been observed in sediment slurries, with predominant formation of $\mathrm{NH}_{4}^{+}$, and some $\mathrm{N}_{2}$ production from RDX (Smith et al., 2015b; Ariyarathna et al., 2016). A small fraction of the mineralized TNT-N can be incorporated into photo- and hetero-trophic biomass such as nucleic acids (Roh et al., 2009; Hatzinger and Fuller, 2014; Smith et al., 2015a).

\section{RDX and HMX Transformation and Mineralization}

RDX and HMX appear to follow similar transformation and mineralization pathways (Figure 9), although RDX has been far more intensively studied. Both compounds undergo reduction to nitroso derivatives, which can also act as intermediates to further degradation (McCormick et al., 1981, 1984). Ringcleavage of RDX, HMX, or their nitroso forms results in complete mineralization or formation of the intermediate compounds methylenedinitramine (MEDINA) or nitrodiazabutanal (NDAB) (Hawari et al., 2000a; Jackson et al., 2007; Monteil-Rivera et al., 2009). The nitroso derivatives and NDAB formed by transformation or mineralization of $\mathrm{RDX}$ are relatively stable under most environmental conditions, while MEDINA is unstable (Paquet et al., 2011). Sea salts may enhance the stability of MEDINA (Paquet et al., 2011).

Both RDX and HMX showed mineralization to $\mathrm{CO}_{2}$ in radiolabel experiments with marine sediments (Lotufo et al., 2001; Pennington et al., 2011). Limited RDX mineralization was observed in wetland experiments (Best et al., 1999). Mineralization of RDX has been reported under remediation conditions by photolysis (Yardin and Chiron, 2006) and alkaline hydrolysis (Felt et al., 2001). Mineralization of RDX and HMX by abiotic alkaline hydrolysis has also been reported for marine waters, although rates were slow and highly temperaturedependent, with half lives on the order of decades or longer under environmental temperatures (Monteil-Rivera et al., 2008).

Marine mesocosm experiments using ${ }^{15} \mathrm{~N}-\mathrm{RDX}$ showed greater than $50 \%$ removal over a 3 -week incubation period (Smith et al., 2015b). Approximately $30 \%$ of the loss occurred by remineralization to dinitrogen gas. The authors argued 
that this denitrification proceeds via ring cleavage, and that subsequent degradation led to formation of undetected products that represented the balance of removed RDX label. Subsequent investigation showed some production of MEDINA followed by $\mathrm{NH}_{4}^{+}$, with the majority of the RDX label in unidentified pools (Ariyarathna et al., 2016).

In one study comparing different estuarine systems, RDX and HMX mineralization in sediments was only reported for one site (Kahana Bay, Hawaii), at locations with salinity equal to or greater than 15\%o (Montgomery et al., 2011a). RDX and HMX mineralization rates were approximately five-fold lower than those for TNT. In a similar study, RDX and HMX mineralization was observed in water and sediments from sites in Florida (USA), with rates comparable to TNT (Montgomery et al., 2014).

\section{PHOTOLYSIS}

Light absorption by TNT is strongest at approximately $235 \mathrm{~nm}$, and generally higher at wavelengths shorter than $300 \mathrm{~nm}$ (Li et al., 1998). RDX and HMX both absorb light most strongly at approximately $190 \mathrm{~nm}$ (Smit, 1991). Consistent with absorption in the UV range, MC photodegradation in seawater occurs at wavelengths below $320 \mathrm{~nm}$ (Luning Prak et al., 2013). Interestingly, Mabey et al. (1983) showed that TNT photolysis can occur in natural waters by irradiation at wavelengths above $420 \mathrm{~nm}$, indicating that light absorption by solutes such as humics can indirectly promote TNT degradation (Dunnivant et al., 1992). Irradiance decreases rapidly with depth in the ocean, although less at short wavelengths than long wavelengths. In colored, productive, or turbid coastal waters such as the Baltic Sea, irradiance can decrease by several orders of magnitude within only a few meters of the surface (Wozniak and Dera, 2007). Consequently, photolysis and photodegradation of MC likely play a role only in very shallow or clear waters. Nonetheless, the fast rate and extent of MC photo reactions make them potentially important in MC persistence in the marine environment. In addition, photodegradation of many MC appears to create products that are more toxic than the initial parent compounds (Dave et al., 2000; Woodley and Downs, 2014).

Photodegradation is particularly important for TNT, and can produce a variety of reaction products with a range of stabilities (Figure 8) (Burlinson et al., 1979b). Photolysis halflives of TNT and DNT in natural waters are on the order of $10^{0}-10^{1} \mathrm{~h}$ (Mabey et al., 1983; Mihas et al., 2007). The predominant product observed in laboratory experiments is ADNBA (Taylor et al., 2010; Luning Prak et al., 2017), which has also been detected in terrestrial and groundwater systems affected by munition compound contamination (Spanggord et al., 1983; Grummt et al., 2006). However, the primary stable product of TNT photolysis under environmental conditions may be TNB, although trinitrobenzaldehyde (TNBCHO), trinitrobenzoic acid (TNBCOOH), and aminodinitrobenzoic acid (ADNBA) are likely more important in seawater (Luning Prak et al., 2017).

In addition to these mono-cyclic compounds, highly-soluble, reddish photoreaction products are widely observed to form
(Kaplan et al., 1975; Spanggord et al., 1980; Mabey et al., 1983; Taylor et al., 2009). Photochemical degradation of DNT produces similar colored high-molecular weight products (370$430 \mathrm{~g} \mathrm{~mol}^{-1}$ ) (Nipper et al., 2004). Taylor et al. (2010) provide the most extensive investigation of these colored TNT photodegradation compounds. The authors demonstrated that the reddish compounds form only under damp or wet conditions (cf. Kunz et al., 2012; Gares et al., 2014). Following dissolution of TNT, photochemical reaction produces a TNT anion that condenses with itself to form an unstable red-colored intermediate compound. This intermediate can dissociate back to TNT, or hydrolyze further to form a stable red-colored product that is acidic and water-soluble.

Photolysis rates for TNT increase with salt concentration (e.g., pure water $<<$ natural fresh water $<$ estuarine water $<$ seawater), from $10^{1} \mathrm{~h}$ in deionized water to $10^{0} \mathrm{~h}$ in seawater (Luning Prak et al., 2013; Sisco et al., 2015). Photolysis of DNT increased by a factor of three in seawater and $\mathrm{NaCl}$ solutions compared with distilled water (Mihas et al., 2007). The reaction rate in seawater was nearly 5 -fold slower after the seawater was passed over a Chelex resin column to remove trace metals (Luning Prak et al., 2013). This suggests that the photolysis rate increase observed in seawater may not be due solely to major salts (see also section on Fenton Reaction, below). This is consistent with other studies showing enhanced photodegradation in the presence of metals such as $\mathrm{Fe}(\mathrm{II})$ and $\mathrm{TiO}_{2}$ (Schmelling and Gray, 1995; Liou et al., 2003).

Mabey et al. (1983) showed that TNT photolysis increased by 1-2 orders of magnitude in filtered natural freshwaters compared with distilled water, apparently due to interaction with humic and fulvic substances. A similar effect of dissolved humics has been shown for DNT degradation (Mihas et al., 2007). While there is evidence that photolysis is reduced at low $\mathrm{pH}$ in pure water (Burlinson et al., 1973), the influence of solutes such as humic acids in natural waters are likely to be far more important than pH (Mabey et al., 1983). This is consistent with experiments in marine and estuarine water showing little $\mathrm{pH}$ effect between $\mathrm{pH} 6$ and 8 (Luning Prak et al., 2017). Photolysis of TNT in pure water is enhanced by dissolved nitrate, but there is little evidence that nitrate affects photolysis rates in natural waters (O'Sullivan et al., 2011; Luning Prak et al., 2013).

Photodecomposition can be a major removal pathway for dissolved RDX, producing similar products to biotic degradation including NDAB and smaller inorganics (Figure 9) (Hawari et al., 2002; Monteil-Rivera et al., 2009). RDX photo-reaction rates are much slower than observed for TNT, with a half-life on the order of years (Spanggord et al., 1983). A slight increase in RDX degradation rate was observed in saline vs. fresh waters upon exposure to artificial sunlight (Sisco et al., 2015).

\section{FENTON REACTION}

One possible mechanism for MC degradation or transformation apart from nitro group reduction is via the Fenton reaction, which occurs widely in natural and marine waters (Völker et al., 1997; Qian et al., 2001; Southworth, 2002; White et al., 
2003). Fenton chemistry involves a mixture of $\mathrm{Fe}(\mathrm{II})$ and hydrogen peroxide to generate hydroxyl radicals, which are powerful oxidants. Several studies have examined the potential for Fenton reactions in remediation of TNT in the environment (Ayoub et al., 2010). Fenton degradation of TNT causes oxidation of the methyl group and can produce trinitrobenzoic acid (TNBA) and TNB (Figure 8) (Hess et al., 2003; Jarand et al., 2011). Alternatively, TNT- and TNB-hydroperoxyl radical formation can lead to denitration and hydroxylation, leading to trihydroxybenzene and eventually oxalic acid (Hess et al., 2003). One study suggested that ADNT can also be formed by Fenton reaction in the presence of glucose and cyclodextrins (Jarand et al., 2011), although the nitro-group reduction pathway has not been widely reported. Fenton degradation of nitrotoluenes and their amine derivatives has also been demonstrated, and showed oxidation of the methyl group, deamination, and cleavage of nitro groups (Li et al., 1998; Schmidt and Butte, 1999). Degradation of RDX and HMX has also been shown to occur via a Fenton mechanism (Zoh and Stenstrom, 2002; Oh et al., 2003), although at rates slower than TNT (approximately 85, 60, and $2 \mathrm{~d}^{-1}$ for TNT, RDX, and HMX, respectively) (Liou et al., 2003).

\section{SORPTION}

Solute partitioning among dissolved and particulate phases is commonly described using two different sorption models: Freundlich, and Langmuir (Barrow, 2008). In the Freundlich model, the concentration of sorbed constituent $\left(C_{s}\right)$ is related to the concentration of the dissolved constituent $\left(C_{d}\right)$ by the Freundlich sorption/partitioning coefficient, $\mathrm{K}_{\mathrm{F}}$ :

$$
C_{s}=K_{F} C_{d}^{n}
$$

The superscript, $n$, represents a unitless coefficient of linearity; when $n$ is equal to unity, the constituent exhibits linear sorption (i.e., the expression reduces to the common distribution coefficient, $K_{d}$ ).

The Langmuir model describes sorption in terms of saturation of the sorbent surface sites:

$$
C_{s}=\frac{K_{L} C_{s}^{\max } C_{d}}{1+K_{L} C_{d}}
$$

Where, $K_{L}$ is the Langmuir sorption coefficient, and $C_{s}^{\max }$ is the maximum number of surface sites available to the constituent.

Sorption of TNT, RDX, and HMX all appear to follow Freundlich behavior (Table 4) (Lee and Stenstrom, 1996; Alavi et al., 2011; Sharma et al., 2013) (but cf. Haderlein and Schwarzenbach, 1993), although the non-linear behavior may only manifest at high concentrations (Sharma et al., 2013) and therefore not be evident under most marine conditions. At lower concentrations, linear sorption equations appear appropriate.

Salinity appears to be less important for TNT, RDX, and HMX sorption than the solid phase characteristics (Table 4), although this issue has only been addressed in very few studies. Brannon et al. (2005) found a nearly perfect 1:1 relationship between partition coefficients of RDX and HMX measured in fresh vs. saline water. Sorption of TNT and RDX decreases with increasing temperature, although the magnitude of the effect varies with sediment type (Ariyarathna et al., 2016).

\section{TNT}

TNT exhibits weak sorption to soils and sediments $\left(\mathrm{K}_{\mathrm{d}}\right.$ on the order of $10^{1}$; Table 4), although degradation and subsequent sorption of the metabolites can represent a major removal pathway for dissolved TNT (Elovitz and Weber, 1999). Adsorption-desorption curves for TNT and its degradation products generally show hysteresis (Hatzinger et al., 2004; Falone et al., 2006; Singh et al., 2010; Hao et al., 2018), indicating that sorption is not fully reversible.

Evidence for the dominant solid phase controlling MC sorption is ambiguous, with some studies indicating that a combination of clays and organic matter enhance sorption (e.g., Dontsova et al., 2009). TNT shows particular affinity for organic matter, especially humic- and fulvic-like substances (Li et al., 1997; Achtnich et al., 1999; Falone et al., 2006; Sharma et al., 2013; Hao et al., 2018). Adsorbed organic matter appears to have little influence on MC sorption (Weissmahr et al., 1999).

TNT also exhibits substantial adsorption to clay minerals (Haderlein et al., 1996), especially 2:1 clays such as montmorillonite (Table 4) (Price et al., 2000; Brannon et al., 2002). In some soils, clay minerals are more important for total sorption than organic matter (Weissmahr et al., 1999). This is consistent with the reported dependence of TNT sorption on cation exchange capacity (CEC) (Brannon et al., 1999, 2002). Saturation of clay surface exchange sites with singly-charged cations such as $\mathrm{K}^{+}$and $\mathrm{NH}_{4}^{+}$promotes increased sorption of TNT, by as much as several orders-of-magnitude (Haderlein and Schwarzenbach, 1993; Haderlein et al., 1996; Price et al., 2000; Brannon et al., 2002; Charles et al., 2006). This does not appear to be the case for RDX or HMX (Brannon et al., 2002).

Other minerals such as amorphous and crystalline $\mathrm{Fe}$ oxide minerals are also abundant in marine systems, but evidence for their effect on TNT sorption to sediments is equivocal (Pennington and Patrick, 1990; Ainsworth et al., 1993; Weissmahr et al., 1998). Dontsova et al. (2009) argue that Fe oxides may even interfere with TNT sorption to clays. In general, Fe oxides and calcium carbonate do not appear to sorb TNT strongly (Table 4) (Weissmahr et al., 1998).

\section{TNT Transformation Products}

Sorption of ADNT to topsoils in one study was only slightly higher than for TNT (7.9 vs. $\left.6.4 \mathrm{~L} \mathrm{~kg}^{-1}\right)$, whereas DANT sorption was much higher $\left(12.0 \mathrm{~L} \mathrm{~kg}^{-1}\right)$ (Sheremata et al., 1999). In contrast, sorption to pure illites (also 2:1 clay) was highest for TNT (223 $\mathrm{L} \mathrm{kg}^{-1}$ ), and lower for ADNT and DANT (59 and $20 \mathrm{~L} \mathrm{~kg}^{-1}$, respectively) (Sheremata et al., 1999). All of these compounds show desorption hysteresis. Sorption of TNT degradation products, 2,4-dinitrotoluene and nitrobenzene, was more strongly controlled by soil organic matter than clay minerals (Zhang et al., 2009).

Experiments using radiolabeled MCs have shown that TNT degradation products are often bound in solvent non-extractable forms (Caton et al., 1994; Pennington et al., 1995; Achtnich 


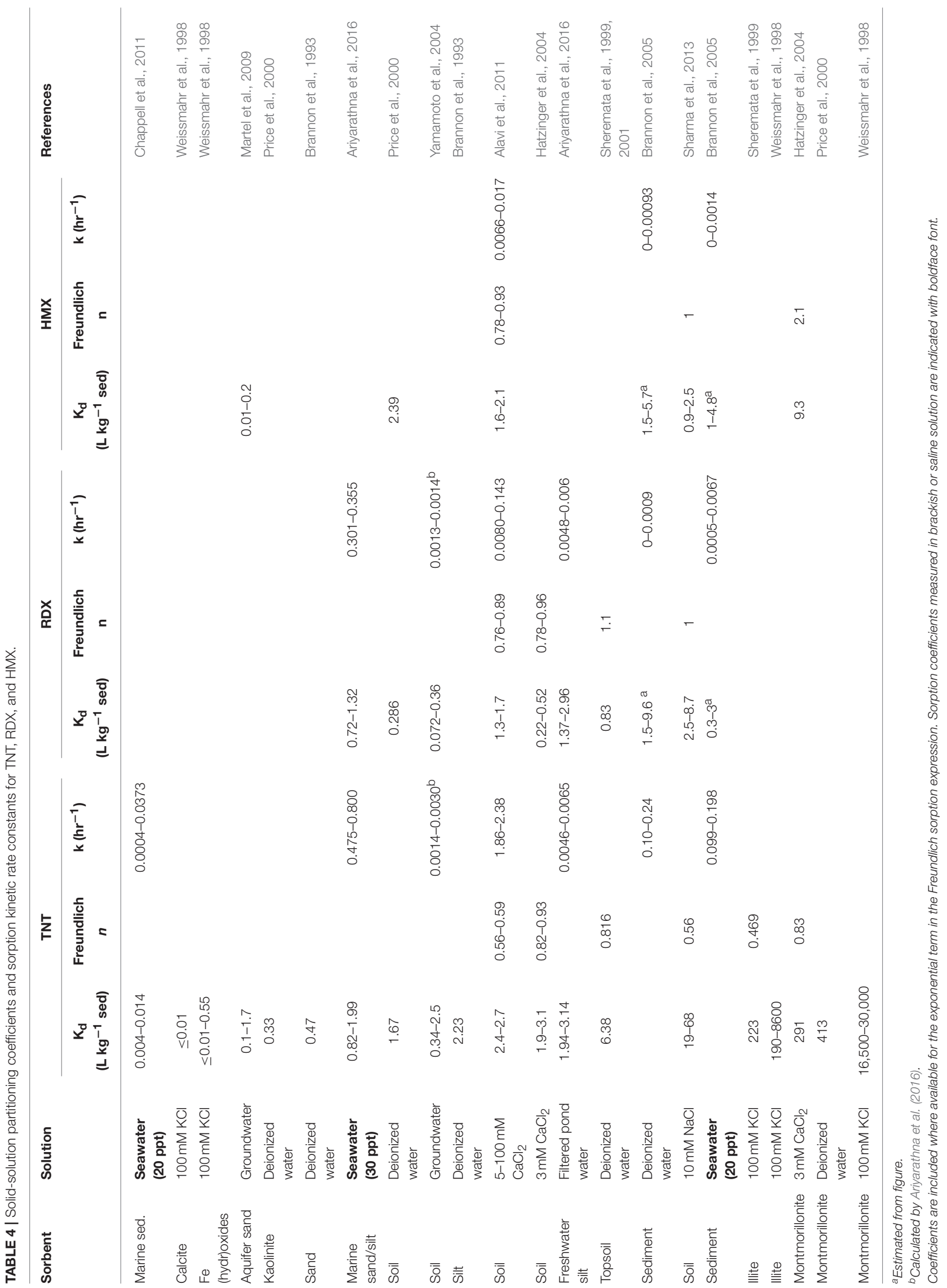


et al., 1999). These irreversibly bound products are formed in a two-step process, with the initial form extractable by acid or acid-base hydrolysis (Thorne and Leggett, 1997). The major reductive degradation products of TNT (ADNTs, DANTs, and TAT) react with soil humic acids to form both heterocyclic and nonheterocyclic condensation products (Bruns-Nagel et al., 2000; Thorn and Kennedy, 2002). Reaction with quinone groups in humic acids has been proposed to explain the greater extent of irreversible binding observed in oxic sediments than reducing sediments (Elovitz and Weber, 1999), depending on whether redox equilibrium favors the oxidized quinone or reduced hydroquinone form (Thorn and Kennedy, 2002). Sorption of DANT to sediments is rapid and virtually irreversible under oxic conditions (Elovitz and Weber, 1999). Carbonyl functional groups have also been implicated in controlling sorption of TNT to sediments (Singh et al., 2010).

\section{RDX and HMX}

RDX and HMX exhibit low, but nearly irreversible sorption to soils, with partition coefficients on the order of $10^{-1}-10^{1} \mathrm{~L} \mathrm{~kg}^{-1}$ (Table 4). RDX transformation products (MNX, DNX, TNX) do not appear to sorb readily to solid surfaces (Sheremata et al., 2001; Heerspink et al., 2017). RDX and HMX both exhibit sorption hysteresis (Hatzinger et al., 2004). Similar to TNT, RDX adsorbs strongly to soils rich in humic substances (Falone et al., 2006), although there is also evidence for a substantial control of clays on adsorption to solids (Dontsova et al., 2009). Some evidence suggests that $\mathrm{Fe}$ oxide minerals may enhance RDX sorption (Dontsova et al., 2009).

Adsorbed RDX is not fully mineralized by microbial degradation, progressing only as far as its nitroso products (Sheremata et al., 2001), although the extent of degradation may also depend on geochemistry of the solid phase (Katseanes et al., 2017). Recovery of RDX from sediment incubations is poor, with sorption being limited but nearly irreversible (Sheremata et al., 2001). Limited sorption or degradation of RDX suggests that following dissolution of mixed munition material, it may be transported farther than TNT, as observed in groundwater systems (Spalding and Fulton, 1988).

\section{TOXICITY}

Of the three MC discussed in this review, only TNT and RDX appear to exhibit toxicity to biological receptors (Table 5). Biological uptake of HMX has been observed (Rosen and Lotufo, 2010), but no toxicity was evident at any of the levels tested (Table 5). In general, dissolved TNT is more toxic than RDX to marine organisms, with acute toxicity occurring at approximately $10^{0}$ and $10^{1} \mu \mathrm{g} \mathrm{L}^{-1}$ levels, respectively. There is some evidence that TNT transformation products (i.e., ADNTs and DANTs) may be more toxic than the TNT parent, but studies evaluating these compounds are generally limited or lacking for the marine environment (Lotufo et al., 2013). TNT and RDX both exhibit genotoxic effects, whereas HMX does not (Inouye et al., 2009). In mammals, TNT is more cytotoxic than RDX, but effects for either are only evident at very high exposure levels $(\sim 1 \mathrm{~g}$ $\mathrm{kg}^{-1}$ body weight) (Cenas et al., 2009). Sub-lethal response to
TNT and RDX exposure has been reported, and includes effects on growth, reproduction, germination, and gene transcription (Table 5). Sub-lethal effects of TNT on nervous, immune, and blood systems have been shown for earthworms (Gong et al., 2007).

Corroded munitions may also act as hard substrate habitat for organisms (McDonald, 2009; Della Torre et al., 2010), increasing the likelihood of food web exposure to munition related chemicals. Certainly, sessile organisms growing on or directly adjacent to munitions appear to experience the greatest exposure (Porter et al., 2011). Exposed munition material appears resistant to biofouling (Dave, 2003), suggesting that direct contact may be toxic to biota. Qualitative indications of stress in corals growing near underwater munitions have been attributed to MC toxicity (Porter et al., 2011). Chemicals (including ammonium picrate, an ammonium salt of 2,4,6-trinitrophenol) recovered from depth charges (UXO) have been shown to be toxic at high concentrations to reef-dwelling damselfish (Jameson, 1975).

One study directly examined toxicity of sea-dumped munitions to marine organisms (Ek et al., 2006). Artillery shells were sliced open and stored in open, sediment-filled boxes on the seafloor. Sediment toxicity to copepods was observed within 3 months, but no increase in toxicity occurred over three subsequent years, and sediments were not toxic to two other crustaceans tested over the entire period. No TNT uptake or toxicity was observed in fish and mussels deployed near the open munitions. Toxicity of TNT exposure increases with temperature (Ek et al., 2008), as does dissolution from solid munition material (see above), suggesting a dual effect of temperature on exposure and toxic response.

Adsorption of dissolved MC to particles and sediments may reduce toxicity of $\mathrm{MC}$ to organisms, and while most of the MC in sediments is not solvent-extractable, the solvent labile fraction has been argued to be the bioavailable component (Hundal et al., 1997). Accumulation of TNT in plants grown in contaminated soil was inversely proportional to the organic matter content of the soils, demonstrating that sorption or complexation of MC may decrease bioavailability in sedimentary systems (Cataldo et al., 1989). Similarly, sediment addition to experiments with copepods and amphipods also decreased toxicity, but only after aging, either due to slow sorption rates or microbial degradation (Dave et al., 2000; Pennington et al., 2011).

Marine algae accumulate dissolved TNT and RDX, and metabolize both to some extent (Cruz-Uribe et al., 2007; Ballentine et al., 2016), whereas TNT is metabolized in mussels but RDX and HMX are not (Rosen and Lotufo, 2007). Bioaccumulation of these $\mathrm{MC}$ from aqueous exposure and ingestion in benthic invertebrates and fish appears to be low, and depuration rates relatively high (half-life on the order of hours) (Belden et al., 2005; Lotufo and Lydy, 2005; Ownby et al., 2005; Rosen and Lotufo, 2007; Lotufo et al., 2016). In contrast, TNT transformation products do tend to bioaccumulate to a greater extent, and are depurated more slowly (Belden et al., 2005; Lotufo et al., 2016). Nonetheless, depuration of MC in marine biota may explain why some marine organisms at contaminated sites do not exhibit high levels of MC in tissues (Koide et al., 2016). Less than $20 \%$ of the accumulated MC could be extracted in 
TABLE 5 | Acute and sublethal toxicity of TNT, RDX, and HMX to marine organisms.

\begin{tabular}{|c|c|c|c|c|c|c|c|c|}
\hline MC & $\begin{array}{l}\text { Exposure } \\
\text { type }\end{array}$ & Organism & Duration (d) & $\begin{array}{l}\text { Acute toxicity } \\
\text { (mg L-1, } \\
\text { dissolved; } \mu \mathrm{g} \\
\mathrm{g}^{-1} \text { sediment) }\end{array}$ & $\begin{array}{c}\text { Tissue } \\
\text { residue } \\
(\mu \mathrm{g} / \mathrm{g})\end{array}$ & $\begin{array}{c}\text { Sub-lethal } \\
\text { conc. (mg } \mathrm{L}^{-1} \text {, } \\
\text { dissolved; } \mu \mathrm{g} \\
\mathrm{g}^{-1} \text { sediment) }\end{array}$ & Sublethal effect & References \\
\hline \multirow[t]{8}{*}{ TNT } & Water & Fish & $2-10$ & $1.7-7.6$ & & & & $\begin{array}{l}\text { Nipper et al., 2001; Ek } \\
\text { et al., 2008; Lotufo } \\
\text { et al., 2010 }\end{array}$ \\
\hline & & Copepod & $3-4$ & $2-7.6$ & & & & $\begin{array}{l}\text { Won et al., 1976; Dave } \\
\text { et al., 2000; Ek et al., } \\
\text { 2008; Liang et al., } 2017\end{array}$ \\
\hline & & Polychaete & 7 & 5.6 & & & & Nipper et al., 2001 \\
\hline & & Echinoderm & 2 & $>9.1$ & & $10-12$ & Embryo develop & $\begin{array}{l}\text { Davenport et al., 1994; } \\
\text { Nipper et al., } 2001\end{array}$ \\
\hline & & Coral & $1-4$ & & & $0.1-5.4$ & $\begin{array}{l}\text { Tissue integrity, } \\
\text { porphyrin levels }\end{array}$ & $\begin{array}{l}\text { Woodley and Downs, } \\
2014\end{array}$ \\
\hline & & Algae & 4 & $>2.1$ & & 2.5 & Germling length & Nipper et al., 2001 \\
\hline & Sediment & Amphipod & $10-28$ & $23-177$ & $2.6-8.9$ & $177-217$ & $\begin{array}{l}\text { Growth and } \\
\text { reproduction }\end{array}$ & $\begin{array}{l}\text { Green et al., 1999; } \\
\text { Rosen and Lotufo, } \\
2005\end{array}$ \\
\hline & & Polychaete & $10-28$ & 400 & 61 & & None observed & Green et al., 1999 \\
\hline \multirow[t]{7}{*}{ RDX } & Water & Fish & $4-28$ & $2.4-9.9$ & & & & $\begin{array}{l}\text { Lotufo et al., 2010, } \\
2017\end{array}$ \\
\hline & & Shrimp & 4 & $47-53$ & & & & Lotufo et al., 2017 \\
\hline & & Amphipod & 4 & $>39$ & & & & Lotufo et al., 2017 \\
\hline & & Coral zooxan. & 5 & $>7.2$ & & 1.8 & Gene transcription & Gust et al., 2014 \\
\hline & & Algae & 4 & & & 12 & Germination & Nipper et al., 2001 \\
\hline & Sediment & Amphipod & $10-28$ & $>1,000$ & $5.6-21$ & $>1,000$ & None observed & $\begin{array}{l}\text { Lotufo et al., 2001; } \\
\text { Rosen and Lotufo, } \\
2005\end{array}$ \\
\hline & & Polychaete & $10-28$ & $>1,000$ & & $>1,000$ & None observed & $\begin{array}{l}\text { Lotufo et al., 2001; } \\
\text { Rosen and Lotufo, } \\
2005\end{array}$ \\
\hline \multirow[t]{4}{*}{ HMX } & Water & Fish & 5 & $>2$ & & & & Lotufo et al., 2010 \\
\hline & & Mollusc & 4 & $>1.9$ & 0.92 & $>1.9$ & None observed & $\begin{array}{l}\text { Rosen and Lotufo, } \\
2007\end{array}$ \\
\hline & Sediment & Amphipod & $10-28$ & $>300$ & & & & Lotufo et al., 2001 \\
\hline & & Polychaete & $10-28$ & $>200$ & & & & Lotufo et al., 2001 \\
\hline
\end{tabular}

"Tissue residue" refers to the toxic tissue level where toxicity was observed, or tissue concentration at the highest tested exposure level.

experiments conducted with ${ }^{14} \mathrm{C}$-labeled TNT, suggesting that tissue MC measurements in field samples underestimate the true body burden (Cataldo et al., 1989; Ownby et al., 2005; Lotufo et al., 2016).
Studies using freshwater minnows showed overt toxicity of RDX only at very high concentrations $\left(10 \mathrm{mg} \mathrm{L}^{-1}\right)$, but there were significant changes in gene transcript expression at much lower concentrations $\left(0.625 \mathrm{mg} \mathrm{L}^{-1}\right)$ (Gust et al., 
2011). Gene functions affected by RDX include such metabolic processes as oxygen transport, neurological function, energy metabolism, and cell growth/division. Gene transcription was also depressed in coral zooxanthellae by RDX concentrations of $1.8 \mathrm{mg} \mathrm{L}^{-1}$, for genes involved in photosynthesis, glycolysis, and electron-transport functions (Gust et al., 2014). Marine organisms tend to exhibit enhanced sensitivity to MC relative to freshwater organisms (Talmage et al., 1999; Nipper et al., 2009; Lotufo et al., 2017), suggesting that similar effects may impact marine organisms at even lower concentrations. This highlights the importance of sublethal effects of MC exposure to aquatic organism health, and predictions based on acute toxicity thresholds may underestimate the threat to marine ecosystems.

Although toxic effects of conventional munitions may be sublethal and difficult to detect, release of compounds from chemical munitions has been implicated in elevated genotoxicity and cytotoxicity observed in fish collected near munitions dumpsites in the Baltic Sea (Baršiene et al., 2014). Results were similar for fish collected near a chemical munitions site in the Adriatic Sea (Della Torre et al., 2010), although no munitions compounds were detected in fish tissues (Amato et al., 2006a). Fish at the site did have higher levels of $\mathrm{Hg}$ and As compared to reference sites (Amato et al., 2006a; Della Torre et al., 2010).

Nipper et al. (2009) reviewed toxicity data for TNT on marine organisms, and suggested a TNT Water Quality Criteria (WQC) of 85.4 and $28.4 \mu \mathrm{g} \mathrm{L}^{-1}$ for acute and chronic toxicity, respectively. In a more recent review, Lotufo et al. (2017) argued for a WQC of 398 and $32.6 \mu \mathrm{g} \mathrm{L}^{-1}$ for acute and chronic toxicity, respectively. There are fewer estimates for RDX, and the only reported marine WQC is approximately $850 \mu \mathrm{g} \mathrm{L}^{-1}$ for both acute and chronic toxicity, seven-fold lower than estimated for freshwater organisms (Lotufo et al., 2017). No estimates are available for toxicity of HMX to marine organisms, but freshwater WQCs are 3800 and $330 \mu \mathrm{g} \mathrm{L}^{-1}$ (Talmage et al., 1999).

It is important to note that toxicity experiments can be difficult to perform due to changes in MC concentration as a result of biogeochemical processes such as sorption or degradation (e.g., Rosen and Lotufo, 2005). Static renewal and constant exposure experiments showed as much as two ordersof-magnitude variation in concentration over time, especially at the lowest nominal concentration (Lotufo et al., 2013). On the other hand, processes such as phototransformation or photoactivation may enhance MC toxicity (Davenport et al., 1994; Johnson et al., 1994; Dave et al., 2000; Woodley and Downs, 2014), and transformation over the course of an experiment may change the actual type of chemical exposure.

\section{CONCLUSIONS AND OUTLOOK FOR FUTURE WORK}

There is a vast quantity of relic munitions on the coastal seafloor, especially in North America, Europe, and the southwest Pacific. In total, these munitions must represent millions of tons of explosive material, a chemical point source of very poorly constrained magnitude. The location, quantity, and identity of munitions were often poorly documented during disposal, and much of the information that does exist may be yet unknown. Sifting through and distilling century-old archives to compile a reliable history of dumping activities is a daunting task, made more difficult because of political and language borders, military classified restrictions, and few experts who understand the specific military slang of that time.

Subsea technology is rapidly maturing to meet the challenge of mapping and identifying underwater munitions. Approaches such as side-scan and multibeam sonar, sub-bottom profiling, and magnetometry have all proved successful for mapping the distribution of DMM and UXO, at least on a local scale. The required effort and cost thus far prohibit broad-scale seafloor imaging at a sufficiently high resolution to detect munitions on the seafloor and in the sub-seafloor. Nonetheless, increasing development of offshore infrastructure such as aquaculture, wind farms, cables, and oil and gas pipelines provides impetus for ongoing improvement of munition detection tools.

Where the location of DMM is known, such as the historical dumping grounds marked explicitly on nautical maps, the risk of chemical release remains uncertain. A number of anecdotal estimates for the corrosion lifetime of underwater munitions appear in fact to be corroborated by visual analysis. The integrity of DMM casings varies widely, but many recent reports suggest that deterioration is widespread. The explosive material that was fully encased for decades may now be increasingly exposed to marine waters and ecosystems. The cessation of seadumping of munitions has certainly helped prevent additional ocean pollution, but current and future release of contaminants from relic underwater munitions threatens to undermine the United Nations Development Goal 14 to reduce marine pollution (United Nations, 2017).

The chemical contamination associated with underwater conventional munitions appears almost exclusively to be organic energetic compounds. While munitions do contain toxic metals such as mercury and lead, high environmental (albeit, mostly anthropogenic) background makes it difficult to conclusively identify metals derived from a munition source. However, very few studies have addressed this metal contamination, and definitive identification may require sampling with higher statistical strength, or use of unique source tracers such as metal isotope ratios. Given that toxic metals are one component of the complex chemical point source from munitions, they may add to an overall negative ecological impact on associated biological communities.

Laboratory experiments suggest that temperature has a strong effect on dissolution of solid explosive material, whereas salinity and $\mathrm{pH}$ are likely less important. Over the relevant environmental range, temperature may effect a 4- to 6-fold variation in solubility. The few field studies that have been able to collect water samples very close to or within breached munitions show that dissolved munition compound concentrations approach solubility limits ( $\mathrm{mg} \mathrm{L}^{-1}$ range). Different trends in MC solubility with temperature suggest that a mixed or composite solid explosive source will represent a changing MC source profile over time. Dissolved MCs are rapidly diluted away from the munition point source, and analytical detection limits have 
largely prevented quantification at levels present in the free water column or sediments (typically at the $\mathrm{ng} \mathrm{L}^{-1}$ or $\mu \mathrm{g} \mathrm{kg}^{-1}$ level).

The rates of MC dissolution from solid explosives have been studied extensively under controlled experimental conditions, but do not appear to adequately represent conditions relevant to underwater munitions. At the median value for dissolution found in the literature, the surface of solid explosives should retreat on the order of $10 \mathrm{~s}$ of $\mathrm{cm}$ every year. This is contradicted by qualitative in situ observations that exposed solid explosives do not experience rapid erosion. In situ measurements of explosive dissolution would greatly help to constrain realistic rates, but the inherent hazard of working with explosives appears to have thus far prevented such work.

Once released from solid explosives, TNT is readily transformed by bacteria and fungi to various amino-toluene derivatives, but probably does not undergo ring cleavage and mineralization. Photochemical and abiotic reaction pathways may result in more complete degradation, but the aromatic structure can be preserved in reaction products such as nitrobenzenes. This suite of TNT daughter products can provide some indication of dominant reaction pathways, and they may prove an important tool for evaluating environmental fate and transport controls. Nonetheless, it is an analytical challenge to measure such a broad set of compounds, and the most widely-applied, HPLC-based EPA 8330 method is not sufficient. In contrast to TNT, RDX and HMX have a greater ability to be fully mineralized. Reaction rates tend to be slow, but result ultimately in destruction of the compounds.

Limited partitioning of MCs onto particles suggests the possibility for long-range transport, especially the less-reactive RDX and HMX. The amino forms of TNT transformation products exhibit increased affinity for particle surfaces with increasing number of amino groups, which may lead to fractionation of TNT and its metabolites along transport paths. The terminal TNT degradation product, TAT, is unlikely to persist in the dissolved phase in oxic marine waters. Polymerization and covalent bonding of MC and associated daughter products to sediments and organic matter present a technical challenge to recovery from environmental samples. Indeed, even when MC are quantitatively recovered, sediment and biota MC content is usually on the order of $\mu \mathrm{g} \mathrm{kg}^{-1}$, and presents an analytical challenge nonetheless.

\section{REFERENCES}

Achtnich, C., Sieglen, U., Knackmuss, H. J., and Lenke, H. (1999). Irreversible binding of biologically reduced 2,4,6-trinitrotoluene to soil. Environ. Toxicol. Chem. 18, 2416-2423. doi: 10.1002/etc.5620 181106

Ainsworth, C. C., Harvey, S. D., Szecsody, J. E., Simmons, M. A., Cullinan, V., Resch, T. C., et al. (1993). Relationship Between the Leachability Characteristics of Unique Energetic Compounds and Soil Properties. U.S. Army Medical Research and Development Command, Frederick, MD. Report: AD-A267 580. p. 138.
In general, toxicity studies suggest that levels of MC at munitions-contaminated sites are unlikely to have an adverse effect on biota. Certainly, acute toxicity is highly unlikely. However, it is not clear how well toxicological experiments represent natural communities or in situ conditions. Benthic and epifaunal organisms may be uniquely exposed to MC where corrosion or low-order detonation leave exposed munition material on the seafloor. There is also growing evidence that munition-related chemicals can cause sublethal genetic and metabolic effects in aquatic organisms. Examining the occurrence of MC in natural ecosystems may help clarify potential effects, but analytical difficulty extracting and analyzing $\mathrm{MC}$ in tissue remains a challenge.

The study of munitions-related chemicals in the marine environment has been active for nearly a half century, yet we lack a fundamental understanding of MC distribution and behavior in the marine environment. Much of this knowledge gap results from inability to sensitively and specifically measure $\mathrm{MC}$ in marine samples, as well as difficulties working with inherently dangerous materials. Advances in mass spectrometry are improving the outlook of the former aspect, but standardization, laboratory intercomparison, and standard reference benchmarks will need to be improved if global research efforts are to be unified. Collaboration between civil and military scientists may be hampered by traditional institutional borders, but is important for bringing together the necessary expertise on munitions materials and marine biogeochemistry. With increasing economic activity in coastal waters, and the apparent impending corrosion threshold, concerted effort to understand the global inventory of underwater munitions is more urgent than ever.

\section{AUTHOR CONTRIBUTIONS}

EA, JG, and CS conceived of the project. AB drafted the manuscript with substantial contributions to the work by all authors. The manuscript was edited and approved by all authors.

\section{FUNDING}

This work was funded by the German Federal Ministry of Education and Research (BMBF) through the project UDEMM (Umweltmonitoring für die DElaboration von Munition im Meer, Project number 03F0747A, B, C).
Aker, J., Howard, B., and Reid, M. (2012). Risk management for unexploded ordinance (UXO) in the marine environment. Dalhousie J. Interdiscip. Manag. 8, 1-22. doi: 10.5931/djim.v8i2.366

Alavi, G., Chung, M., Lichwa, J., D’Alessio, M., and Ray, C. (2011). The fate and transport of RDX, HMX, TNT and DNT in the volcanic soils of Hawaii: a laboratory and modeling study. J. Hazard. Mater. 185, 1600-1604. doi: 10.1016/j.jhazmat.2010.10.039

Amato, E., Alcaro, L., Corsi, I., Della Torre, C., Farchi, C., Focardi, S., et al. (2006a). An integrated ecotoxicological approach to assess the effects of pollutants released by unexploded chemical ordnance dumped in the southern Adriatic (Mediterranean Sea). Mar. Biol. 149, 17-23. doi: 10.1007/s00227-005-0216-x 
Amato, E., Alcaro, L., Corsi, I., Della Torre, C., Farchi, C., Giordano, P., et al. (2006b). R.E.D. C.O.D. Project: Research On Environmental Damage Caused By Chemical Ordnance Dumped At Sea. B4-3070/2003/368585/SUB/D.3.

Ampleman, G., Faucher, D., Thiboutot, S., Hawari, J., and Monteil-Rivera, F. (2004). Evaluation of Underwater Contamination by Explosives and Metals at Point Amour, Labrador and in the Halifax Harbour Area. Technical Report DRDC Valcartier TR 2004-125. p. 48.

Appleyard, D. (2015). Avoiding a big bang for your buck. Renew. Energy Focus 16, 138-141. doi: 10.1016/j.ref.2015.10.018

Ariyarathna, T., Vlahos, P., Tobias, C., and Smith, R. W. (2016). Sorption kinetics of TNT and RDX in anaerobic freshwater and marine sediments: batch studies. Environ. Toxicol. Chem. 35, 47-55. doi: 10.1002/etc.3149

Asahina, J. K., Shimoyama, H., Hayashi, K., and Shinkai, A. (2009). Detection, recovery, and destruction system for sea-disposed chemical munitions: Port Kanda, Japan. Mar. Technol. Soc. J. 43, 116-126. doi: 10.4031/MTSJ.43.4.8

Ayoub, K., van Hullebusch, E. D., Cassir, M., and Bermond, A. (2010). Application of advanced oxidation processes for TNT removal: a review. J. Hazard. Mater. 178, 10-28. doi: 10.1016/j.jhazmat.2010.02.042

Badjagbo, K., and Sauvé, S. (2012a). High-throughput trace analysis of explosives in water by laser diode thermal desorption/atmospheric pressure chemical ionization-tandem mass spectrometry. Anal. Chem. 84, 5731-5736. doi: 10.1021/ac300918f

Badjagbo, K., and Sauvé, S. (2012b). Mass spectrometry for trace analysis of explosives in water. Crit. Rev. Anal. Chem. 42, 257-271. doi: 10.1080/10408347.2012.680332

Ballentine, M. L., Ariyarathna, T., Smith, R. W., Cooper, C., Vlahos, P., Fallis, S., et al. (2016). Uptake and fate of hexahydro-1,3,5-trinitro-1,3,5-triazine (RDX) in coastal marine biota determined using a stable isotopic tracer, $15 \mathrm{~N}$ - [RDX]. Chemosphere 153, 28-38. doi: 10.1016/j.chemosphere.2016.03.038

Ballentine, M. L., Tobias, C., Vlahos, P., Smith, R. W., and Cooper, C. (2015). Bioconcentration of TNT and RDX in coastal marine biota. Arch. Environ. Contam. Toxicol. 68, 718-728. doi: 10.1007/s00244-014-0104-9

Banerjee, S. (1980). Water solubility and octanol/water partition coefficients of organics: limitations of the solubility-partition coefficient correlation. Environ. Sci. Technol. 14, 1227-1229. doi: 10.1021/es60170a013

Barrow, N. J. (2008). The description of sorption curves. Eur. J. Soil Sci. 59, 900-910. doi: 10.1111/j.1365-2389.2008.01041.x

Barrows, S. E., Cramer, C. J., Truhlar, D. G., Elovitz, M. S., and Weber, E. J. (1997). Factors controlling regioselectivity in the reduction of polynitraromatics in aqueous solution. Environ. Sci. Technol. 30, 3028-3038. doi: 10.1021/es960004x

Barshick, S. A., and Griest, W. H. (1998). Trace analysis of explosives in seawater using solid-phase microextraction and gas chromatography ion trap mass spectrometry. Anal. Chem. 70, 3015-3020. doi: 10.1021/ac980060b

Baršiene, J., Butrimavičiene, L., Grygiel, W., Lang, T., Michailovas, A., and Jackunas, T. (2014). Environmental genotoxicity and cytotoxicity in flounder (Platichthys flesus), herring (Clupea harengus) and Atlantic cod (Gadus morhua) from chemical munitions dumping zones in the southern Baltic Sea. Mar. Environ. Res. 96, 56-67. doi: 10.1016/j.marenvres.2013.08.012

Bausinger, T., Bonnaire, E., and Preuß, J. (2007). Exposure assessment of a burning ground for chemical ammunition on the Great War battlefields of Verdun. Sci. Total Environ. 382, 259-271. doi: 10.1016/j.scitotenv.2007.04.029

Baytos, J. F. (1980). LASL Explosive Property Data, Vol. 4. Berkeley; Los Angeles, CA: University of California Press.

Bearden, D. M. (2007). U.S. disposal of chemical weapons in the ocean: background and issues for congress. CRS Rep. Congr. Report No. RL33432, 25.

Beddington, J., and Kinloch, A. (2005). Munitions Dumped at Sea: A Literature Review. London, UK: Imperial College Consultants.

Belden, J. B., Lotufo, G. R., Chambliss, C. K., Fisher, J. C., Johnson, D. R., Boyd, R. E., et al. (2011). Accumulation of $14 \mathrm{C}$-trinitrotoluene and related nonextractable (bound) residues in Eisenia fetida. Environ. Pollut. 159, 1363-1368. doi: 10.1016/j.envpol.2011.01.007

Belden, J. B., Ownby, D. R., Lotufo, G. R., and Lydy, M. J. (2005). Accumulation of trinitrotoluene (TNT) in aquatic organisms: Part 2 Bioconcentration in aquatic invertebrates and potential for trophic transfer to channel catfish (Ictalurus punctatus). Chemosphere 58, 1161-1168. doi: 10.1016/j.chemosphere.2004.09.058

Bełdowski, J., Klusek, Z., Szubska, M., Turja, R., Bulczak, A. I., Rak, D., et al. (2016). Chemical munitions search and assessment-an evaluation of the dumped munitions problem in the Baltic Sea. Deep. Res. Part II Top. Stud. Oceanogr. 128, 85-95. doi: 10.1016/j.dsr2.2015.01.017

Benn, A. R., Weaver, P. P., Billet, D. S. M., van den Hove, S., Murdock, A. P., Doneghan, G. B., et al. (2010). Human activities on the deep seafloor in the north east atlantic: an assessment of spatial extent. PLoS ONE 5:e12730. doi: 10.1371/journal.pone.0012730

Berg, M., Bolotin, J., and Hofstetter, T. B. (2007). Compound-specific nitrogen and carbon isotope analysis of nitroaromatic compounds in aqueous samples using solid-phase microextraction coupled to GC/IRMS. Anal. Chem. 79, 2386-2393. doi: 10.1021/ac0622577

Best, E. P. H., Sprecher, S. L., Larson, S. L., Fredrickson, H. L., and Bader, D. F. (1999). Environmental behavior of explosives in groundwater from the milan army ammunition plant in aquatic and wetland plant treatments. removal, mass balances and fate in groundwater of TNT And RDX. Chemosphere 38, 3383-3396. doi: 10.1016/S0045-6535(98)00550-5

Bier, E. L., Singh, J., Li, Z., Comfort, S., and Shea, P. J. (1999). Remediating hexahydro-1,3,5-trinitro-1,2,5-trazine-contaminated water and soil by fenton oxidation. Environ. Toxicol. 18, 1078-1084. doi: 10.1002/etc.56201 80602

Biester, H., Kilian, R., Franzen, C., Woda, C., Mangini, A., and Schöler, H. F. (2002). Elevated mercury accumulation in a peat bog of the Magellanic Moorlands, Chile $\left(53^{\circ} \mathrm{S}\right)$ - An anthropogenic signal from the Southern Hemisphere. Earth Planet. Sci. Lett. 201, 609-620. doi: 10.1016/S0012-821X(02)00734-3

Bohaty, R. F. H. (2009). Lying In Wait. Chem. Eng. News 87, 24-26. doi: 10.1021/cen-v087n013.p024

Bohne, J. (2012). WWII bombs explode at North Sea wind farm. Deutsche Welle. Available online at: http://www.dw.de/wwii-bombs-explode-at-northsea-wind-farm/a-16360735

Boopathy, R., and Manning, J. (1999). Surfactant-enhanced bioremediation of soil contaminated with 2,4,6- trinitrotoluene in soil slurry reactors. Water Environ. Res. 71, 119-124. doi: 10.2175/106143099X121580

Bose, P., Glaze, W. H., and Maddox, D. S. (1998). Degradation of RDX by various advanced oxidation processes: II. Organic by-products. Water Res. 32, 1005-1018. doi: 10.1016/S0043-1354(97)00308-4

Böttcher, C., Knobloch, T., Rühl, N.-P., Sternheim, J., Wichert, U., and Wöhler, J. (2011). Munitionsbelastung der Deutschen Meeresgewässer - Bestandsaufnahme und Empfehlungen (Stand 2011). Meeresumwelt Aktuell Nord- und Ostsee, 2011/3. Hamburg; Rostock: Bundesamt für Seeschifffahrt und Hydrographie (BSH).

Brankowitz, W. R. (1989). Summary of some chemical munitions sea dumps by the United States. 1-51.

Brannon, J. M., Adrian, D. D., Pennington, J. C., and Myers, T. E. (1993). Slow Release of PCB, TNT, and RDX From Soils and Sediments, EL-92-L-38.

Brannon, J. M., and Pennington, J. C. (2002). Environmental fate and transport process descriptors for explosives. Strateg. Environ. Res. Dev. Progr. Install. Restor. Res. Progr. ERDC/ELTR-02-10 ERDC/ELTR-.

Brannon, J. M., Deliman, P., Ruiz, C., Price, C., Gerald, J. A., Hayes, C. A., et al. (1999). Conceptual Model and Process Descriptor Formulations for Fate and Transport of UXO. US Army Corps of Engineers. Report IRRP-99-1

Brannon, J. M., Price, C. B., Hayes, C. A., and Yost, S. L. (2002). Aquifer soil cation substitution and adsorption of TNT, RDX, and HMX. Soil Sediment Contam. 11, 327-338. doi: 10.1080/20025891106772

Brannon, J. M., Price, C. B., Yost, S. L., Hayes, C. A., and Porter, B. (2005). Comparison of environmental fate and transport process descriptors of explosives in saline and freshwater systems. Mar. Pollut. Bull. 50, 247-251. doi: 10.1016/j.marpolbul.2004.10.008

Brewer, P. G., and Nakayama, N. (2008). What lies beneath: a plea for complete information. Environ. Sci. Technol. 86, 1394-1399. doi: 10.1021/es087088h

Brewer, P. G., Hester, K. C., and Nakayama, N. (2008). Chemical weapons on the sea floor: a plea for complete information. Ocean. MTS/IEEE Kobe-TechnoOcean'08 - Voyag. Towar. Futur. OTO'08.

Bromage, E. S., Lackie, T., Unger, M. A., Ye, J., and Kaattari, S. L. (2007). The development of a real-time biosensor for the detection of trace levels of trinitrotoluene (TNT) in aquatic environments. Biosens. Bioelectron. 22, 2532-2538. doi: 10.1016/j.bios.2006.10.001

Bruns-Nagel, D., Knicker, H., Drzyzga, O., Butehorn, U., Steinbach, K., Gemsa, D., et al. (2000). Characterization of 15 N-TNT Residues After an Anaerobic / Aerobic Treatment of Soil / Molasses Mixtures by Solid-State 
15N NMR Spectroscopy.2.Systematic Investigation of Whole Soil and Different Humic Fractions. Environ. Sci. Technol 34, 1549-1556. doi: 10.1021/es990757u

Bull, J. M. R. (2005a). SPECIAL REPORT, PART 1: The Deadliness Below. Daily Press, $1-9$

Bull, J. M. R. (2005b). SPECIAL REPORT, PART 2: The Deadliness Below. Daily Press, 1-8.

Burlinson, N. E., Kaplan, L. A., and Adams, C. E. (1973). Photochemistry of TNT: Investigation of the 'PinkWater' Problem. Silver Spring, MD: Naval Ordnance Laboratory. NOLTR 73-172.

Burlinson, N. E., Sitzman, M. E., Kaplan, L. A., and Kayser, E. (1979b). Photochemical generation of the 2,4,6-trinitrobenzyl anion. J. Org. Chem. 44, 3695-3698. doi: 10.1021/jo01335a 016

Burlinson, N. E., Sitzmann, M. E., Glover, D. J., and Kaplan, L. A. (1979a). Photochemistry of TNT and Related Nitroaromatics: Part III. NSWC/WOL TR 78-198.

Callaway, A., Quinn, R., Brown, C. J., Service, M., and Benetti, S. (2011). Trace metal contamination of Beaufort's Dyke, North Channel, Irish Sea: a legacy of ordnance disposal. Mar. Pollut. Bull. 62, 2345-2355. doi: 10.1016/j.marpolbul.2011.08.038

Camilli, R., Bingham, B. S., Jakuba, M. V., Duryea, A. N., Lebouvier, R., and Dock, M. (2009). AUV sensors for real-time detection, localization, characterization, and monitoring of underwater munitions. Mar. Technol. Soc. J. 43, 76-84. doi: 10.4031/MTSJ.43.4.6

Carton, G., and Jagusiewicz, A. (2011). Historic disposal of munitions in U.S. and European coastal waters, how historic information can be used in characterizing and managing risk. Mar. Technol. Soc. J. 43, 16-32. doi: 10.4031/MTSJ.43.4.1

Cataldo, D. A., Harvey, S. D., Fellows, R. J., Bean, R. M., and McVeety, B. D. (1989). An Evaluation of the Environmental Fate and Behavior of Munitions Materiel (TNT, RDX) in Soil and Plant Systems. US Army Medical Research and Development Command. Report AD-A223 546, 99.

Caton, J. E., Ho, C. H., Williams, R. T., and Griest, W. H. (1994). Characterization of insoluble fractions of TNT transformed by composting. J. Environ. Sci. Heal. Part A Environ. Sci. Eng. Toxicol. 29, 659-670. doi: 10.1080/10934529409376063

Cenas, N., Nemeikaite-Ceniene, A., Šarlauskas, J., Anusevicius, Ž., Nivinskas, H., Miseviciene, L., et al. (2009). "Mechanisms of the mammalian cell cytotoxicity of explosives," in Ecotoxicology of Explosives, eds G. I. Sunahara, G. R. Lotufo, R. G. Kuperman, and J. Hawari (Boca Raton, FL: Taylor and Francis Group, LLC), 211-226.

CH2M HILL (2015). Record Of Decision Unexploded Ordnance 1 (Uxo 1) Eastern Conservation Area Atlantic Fleet Weapons Training Area Former Vieques Naval Training Range (English Version) Vieques Island Puerto Rico. Report EN0822161116TPA, 36 .

Chabert, A. (2016). "The application of marine geophysical methods for unexploded ordnance (UXO) detection," in Presentation. Oceanology International Conference (London), 24.

Chappell, M. A., Price, C. L., and Miller, L. F. (2011). Solid-phase considerations for the environmental fate of nitrobenzene and triazine munition constituents in soil. Appl. Geochem. 26, S330-S333. doi: 10.1016/j.apgeochem.2011.03.067

Charles, S., Teppen, B. J., Li, H., Laird, D. A., and Boyd, S. A. (2006). Exchangeable cation hydration properties strongly influence soil sorption of nitroaromatic compounds. Soil Sci. Soc. Am. J. 70:1470. doi: 10.2136/sssaj2005.0245

CIRIA (2016). Assessment and Management of Unexploded Ordnance (UXO) Risk in the Marine Environment.

Corella, J. P., Valero-Garcés, B. L., Wang, F., Martínez-Cortizas, A., Cuevas, C. A., and Saiz-Lopez, A. (2017). 700 years reconstruction of mercury and lead atmospheric deposition in the Pyrenees (NE Spain). Atmos. Environ. 155, 97-107. doi: 10.1016/j.atmosenv.2017.02.018

Cruz-Uribe, O., Cheney, D. P., and Rorrer, G. L. (2007). Comparison of TNT removal from seawater by three marine macroalgae. Chemosphere 67, 1469-1476. doi: 10.1016/j.chemosphere.2007.01.001

Czub, M., Kotwicki, L., Lang, T., Sanderson, H., Klusek, Z., Grabowski, M., et al. (2018). Deep sea habitats in the chemical warfare dumping areas of the Baltic Sea. Sci. Total Environ. 616, 1485-1497. doi: 10.1016/j.scitotenv.2017.10.165

Darrach, M. R., Chutjian, A., and Plett, G. (1998). A. Trace explosives signatures from World War II unexploded undersea ordnance. Environ. Sci. Technol. 32, 1354-1358. doi: 10.1021/es970992h
Dave, G. (2003). "Field test of ammunition (TNT) dumping in the ocean," in Sediment Quality Assessment and Management: Insight and Progress, ed. M. Munawar (East Lansing, MI: Michigan State University Press), 213-220.

Dave, G., Nilsson, E., and Wernersson, A. S. (2000). Sediment and water phase toxicity and uv-activation of six chemicals used in military explosives. Aquat. Ecosyst. Heal. Manag. 3, 291-299. doi: 10.1016/S1463-4988(00)00032-4

Davenport, R., Johnson, L., Schaeffer, D., and Balbach, H. (1994). Phototoxicology. 1. Light-enhanced toxicity of TNT and some related compounds to Daphnia magna and Lytechinus variagatus embryos. Ecotoxicol. Environ. Saf. 27, 14-22. doi: $10.1006 /$ eesa.1994.1003

Decarlo, E. H., Cox, E. F., and Overfield, M. L. (2007). Ordnance Reef, Wai'anae, Hawai'i: Remote Sensing Survey and Sampling at a Discarded Military Munitions Sea Disposal Site. Marine Sanctuaries Conservation Series NMSP-07-P-01.

Della Torre, C., Petochi, T., Corsi, I., Dinardo, M. M., Baroni, D., Alcaro, L., et al. (2010). DNA damage, severe organ lesions and high muscle levels of As and $\mathrm{Hg}$ in two benthic fish species from a chemical warfare agent dumping site in the Mediterranean Sea. Sci. Total Environ. 408, 2136-2145. doi: 10.1016/j.scitotenv.2010.01.001

Dontsova, K. M., Hayes, C. A., Pennington, J. C., and Porter, B. (2009). Sorption of high explosives to water-dispersible clay: influence of organic carbon, aluminosilicate clay, and extractable Iron. J. Environ. Qual. 38:1458. doi: $10.2134 /$ jeq2008.0183

Dunnivant, F. M., Schwarzenbach, R. P., and Macalady, D. L. (1992). Reduction of substituted nitrobenzenes in aqueous solutions containing natural organic matter. Environ. Sci. Technol. 26, 2133-2141. doi: 10.1021/es000 $35 \mathrm{a} 010$

Edwards, M. H., Shjegstad, S. M., Wilkens, R., King, J. C., Carton, G., Bala, D., et al. (2016). The Hawaii Undersea Military Munitions Assessment. Deep. Res. Part II Top. Stud. Oceanogr. 128, 4-13. doi: 10.1016/j.dsr2.2016.04.011

Edwards, R. (1995). Danger from the deep. New Sci. 148, 16-17.

Efroymson, R. A., Morrill, V., Dale, V. H., Jenkins, T. F., and Giffen, N. R. (2009). "Habitat disturbance at explosives-contaminated ranges," in Ecotoxicology of Explosives, eds G. Sunahara, G. Lotufo, R. Kuperman, and J. Hawari (Boca Raton, FL: CRC Press Taylor and Francis Group), 253-276.

Ek, H., Dave, G., Nilsson, E., Sturve, J., and Birgersson, G. (2006). Fate and effects of 2,4,6-trinitrotoluene (TNT) from dumped ammunition in a field study with fish and invertebrates. Arch. Environ. Contam. Toxicol. 51, 244-252. doi: 10.1007/s00244-005-0117-5

Ek, H., Nilsson, E., and Dave, G. (2008). Effects of TNT leakage from dumped ammunition on fish and invertebrates in static brackish water systems. Ecotoxicol. Environ. Saf. 69, 104-111. doi: 10.1016/j.ecoenv.2006.12.016

Elovitz, M. S., and Weber, E. J. (1999). Sediment-mediated reduction of 2, 4, 6trinitrotoluene and fate of the resulting aromatic (poly)amines. Environ. Sci. Technol. 33, 2617-2625. doi: 10.1021/es980980b

EPA, U. S. (2007). SW-846 Test Method 8330A: Nitroaromatics and Nitramines by High Performance Liquid Chromatography (HPLC).

Erisman, J. W., Sutton, M. A., Galloway, J., Klimont, Z., and Winiwarter, W. (2008). How a century of ammonia synthesis $\backslash$ nchanged the world. Nat. Geosci. 1, 636-639. doi: 10.1038/ngeo325

Falone, S. Z., Vieira, E. M., and Onuska, F. I. (2006). Adsorption study of RDX and TNT explosives in soils by HPLC. J. Liq. Chromatogr. Relat. Technol. 29, 1645-1662. doi: 10.1080/10826070600678373

Felt, D. R., Larson, S. L., and Hansen, L. D. (2001). Molecular Weight Distribution of the Final Products of TNT-Hydroxide Reaction. US Army Corps of Engineers, ERDC/ELTR-01-16.

Fowler, S. W. (1993). Pollution in the Gulf: Monitoring the marine environment. IAEA Bull. 358, 9-13.

Francis, S., and Alama, I. (2011). WWII Unexploded Ordnance: A Study of UXO in Four Pacific Island Countries. Pacific Islands Forum Secretariat.

Frenz, U. (2014). Autonome Unterwasserfahrzeuge mit SAS-Technologie. Lehre und Forsch. 02-2014, 11-16.

Fuller, M. E., Hatzinger, P. B., Rungmakol, D., Schuster, R. L., and Steffan, R. J. (2004). Enhancing the attenuation of explosives in surface soils at military facilities: combined sorption and biodegradation. Environ. Toxicol. Chem. 23, 313-324. doi: 10.1897/03-187

Gapeev, A., Sigman, M., and Yinon, J. (2003). Liquid chromatography/mass spectrometric analysis of explosives: RDX adduct ions. Rapid Commun. Mass Spectrom. 17, 943-948. doi: 10.1002/rcm.1006 
Garcia, S. S., Macdonald, K., De Carlo, E. H., Overfield, M. L., Reyer, T., and Rolfe, J. (2009). Discarded military munitions case study: ordnance reef (HI-06). Hawaii 43, 85-99. doi: 10.4031/MTSJ.43.4.13

Gares, K. L., Bykov, S. V., Godugu, B., and Asher, S. A. (2014). Solution and solid trinitrotoluene (TNT) photochemistry: persistence of TNT-like ultraviolet (UV) resonance Raman bands. Appl. Spectrosc. 68, 49-56. doi: 10.1366/13-07190

Gebka, K., Bełdowski, J., and Bełdowska, M. (2016). The impact of military activities on the concentration of mercury in soils of military training grounds and marine sediments. Environ. Sci. Pollut. Res. 23, 23103-23113. doi: 10.1007/s11356-016-7436-0

George, R., Wild, B., Li, S., Srinivasan, R., Sugamoto, R., Carlson, C., et al. (2015). Recovery Corrosion Analysis, and Characteristics of Military Munitions from Ordnance Reef (HI-06). Report. p. 61.

GICHD (2016). A Guide to Survey and Clearance of Underwater Explosive Ordnance. Geneva: Geneva International Centre for Humanitarian Demining.

Glasby, G. P. (1997). Book review. Sci. Total Environ. 208, 145-147.

Glover, D. J., and Hoffsommer, J. C. (1973). Thin-Layer Chromatographic Analysis of HMX in Water. Bull. Environ. Contam. Toxicol. 10, 302-304. doi: 10.1007/BF01684820

Godejohann, M., Astratov, M., Preiss, A., Levsen, K., Hannover, D.-, and $\mathrm{Mu}, \mathrm{C}$. (1998). Application of continuous-flow HPLC - proton-nuclear magnetic resonance spectroscopy and HPLC - thermospray-mass spectroscopy for the structural elucidation of phototransformation products of 2, 4, 6Trinitrotoluene. Anal. Chem. 2700, 4104-4110. doi: 10.1021/ac980292a

Godschalk, S. K. B., and Ferreira, C. J. (1998). "South Africa’s challenge to manage obsolete ammunition," in IMO/UNEP/IOC Workshop on Waste Management and Marine Pollution Prevention in Southern and Eastern Africa (Cape Town), $1-7$.

Gong, P., Guan, X., Inouye, L. S., Pirooznia, M., Indest, K. J., Athow, R. S., et al. (2007). Toxicogenomic analysis provides new insights into molecular mechanisms of the sublethal toxicity of 2,4,6-trinitrotoluene in Eisenia fetida. Env. Sci Technol 41, 8195-8202. doi: 10.1021/es0716352

Grabowski, M., Fioravanti, S., Been, R., Cernich, F., and Malejevas, V. (2018). "Suitability study of survey equipment used in the MODUM project," in Towards the Monitoring of Dumped Munitions Threat, eds J. Bełdowski, T. Long, and M. Söderström (Dordrecht: Springer Science+Business Media B.V.), 19-47.

Granbom, P. O. (1994). Dumped chemical ammunition in the baltic: a rejoinder. Secur. Dialogue 25, 105-110. doi: 10.1177/0967010694025001009

Granbom, P. O. (1996). "Investigation of a Dumping Area in the Skagerrak, 1992," in Sea-Dumped Chemical Weapons: Aspects, Problems and Solutions, ed A. V. Kaffka (Dordrecht: Springer-Science+Business Media, RY.), 41-48.

Green, A., Moore, D., and Farrar, D. (1999). Chronic toxicity of 2,4,6trinitrotoluene to a marine polychaete and an estuarine amphipod. Environ. Toxicol. Chem. 18, 1783-1790. doi: 10.1002/etc.5620180826

Greene, P., Follett, G., and Henker, C. (2009). The Legacy of Underwater Munitions and Dredging Experience on the United States Coast. Mar. Technol. Soc. J. 43, 127-131. doi: 10.4031/MTSJ.43.4.2

Grummt, T., Wunderlich, H. G., Chakraborty, A., Kundi, M., Majer, B., Ferk, F., et al. (2006). Genotoxicity of nitrosulfonic acids, nitrobenzoic acids, and nitrobenzylalcohols, pollutants commonly found in ground water near ammunition facilities. Environ. Mol. Mutagen. 47, 95-106. doi: $10.1002 / \mathrm{em} .20172$

Gust, K. A., Najar, F. Z., Habib, T., Lotufo, G. R., Piggot, A. M., Fouke, B. W., et al. (2014). Coral-zooxanthellae meta-transcriptomics reveals integrated response to pollutant stress. BMC Genomics 15:591. doi: 10.1186/1471-216415-591

Gust, K. A., Wilbanks, M. S., Guan, X., Pirooznia, M., Habib, T., Yoo, L., et al. (2011). Investigations of transcript expression in fathead minnow (Pimephales promelas) brain tissue reveal toxicological impacts of RDX exposure. Aquat. Toxicol. 101, 135-145. doi: 10.1016/j.aquatox.2010.09.011

HELCOM (1995). Final Report of the ad hoc Working Group on Dumped Chemical Munition (HELCOM CHEMU) to the 16th Meeting of the Helsinki Commission.

Haas, R., and Thieme, J. (1996). Band 2: Explosivstofflexikon. Bestandsaufnahme von Rüstungsaltlastverdachtsstandorten der Bundesrepublik Deutschland, 2. Erweiterte Auflage, Umweltbundesamt [Inventory suspected armament Contam. Fed. Repub. Ger. Second Ext. Ed. Fed. Envi. 378.
Haderlein, S. B., and Schwarzenbach, R. P. (1993). Adsorption of Substituted Nitrobenzenes and Nitrophenols to Mineral Surfaces. Environ. Sci. Technol. 27, 316-326. doi: 10.1021/es00039a012

Haderlein, S. B., Weissmahr, K. W., and Schwarzenbach, R. P. (1996). Specific adsorption of nitroaromatic explosives and pesticides to clay minerals. Environ. Sci. Technol. 30, 612-622. doi: 10.1021/es9503701

Halasz, A., and Hawari, J. (2011). Degradation routes of RDX in various redox systems. ACS Symp. Ser. 1071, 441-462. doi: 10.1021/bk-2011-1071.ch020

Hale, V. Q., Stanford, T. B., and Taft, L. G. (1979). Evaluation of the Environmental Fate of Munition Compounds in Soil. U.S. ARMY MEDICAL RESEARCH AND DEVELOPMENT COMMAND. Fort Detrick, MD. Report ADA082874. p. 111.

Hao, Q.-L., Qiao, H., Zhou, C.-Z., Peng, W., Zhang, K., and Lu, S. (2018). Effects of fulvic acid on TNT adsorption in soil. Soil Sedim. Contamin. 27, 186-199. doi: 10.1080/15320383.2015.1029043

Harrison, I., and Vane, C. H. (2010). Attenuation of TNT in seawater microcosms. Water Sci. Technol. 61, 2531-2538. doi: 10.2166/wst.2010.171

Harvey, S. D., Fellows, R. J., Cataldo, D. A., and Bean, R. M. (1990). Analysis of 2,4,6_trinitrotoluene and its transformation products in soils and plant tissues by high-performance liquid chromatography. J. Chromatogr. 518, 361-374. doi: 10.1016/S0021-9673(01)93196-6

Hatzinger, P. B., and Fuller, M. E. (2014). New Approaches to Evaluate the Biological Degradation of RDX in Groundwater. SERDP Project ER-1607.

Hatzinger, P. B., Fuller, M. E., Rungmakol, D., Schuster, R. L., and Steffan, R. J. (2004). Enhancing the attenuation of explosives in surface soils at military facilities: Sorption-desorption isotherms. Environ. Toxicol. Chem. 23, 313-324. doi: 10.1897/03-186

Hawari, J., Beaudet, S., Halasz, A., Thiboutot, S., and Ampleman, G. (2000a). Microbial degradation of explosives: biotransformation versus mineralization. Appl. Microbiol. Biotechnol. 54, 605-618. doi: 10.1007/s002530000445

Hawari, J., Halasz, A., Beaudet, S., Paquet, L., Ampleman, G., and Thiboutot, S. (2001). Biotransformation routes of octahydro-1,3,5,7-tetranitro-1,3,5,7tetrazocine by municipal anaerobic sludge. Environ. Sci. Technol. 35, 70-75. doi: $10.1021 /$ es 0013531

Hawari, J., Halasz, A., Groom, C., Deschamps, S., Paquet, L., Beaulieu, C., et al. (2002). Photodegradation of RDX in aqueous solution: A mechanistic probe for biodegradation with Rhodococcus sp. Environ. Sci. Technol. 36, 5117-5123. doi: 10.1021/es0207753

Hawari, J., Halasz, A., Paquet, L., Zhou, E., Spencer, B., Ampleman, G., et al. (1998). Characterization of metabolites in the biotransformation of 2,4,6-trinitrotoluene with anaerobic sludge: role of triaminotoluence. Appl. Environm. Microbiol. 64, 2200-2206.

Hawari, J., Halasz, A., Sheremata, T., Groom, C., Paquet, L., Rhofir, C., et al. (2000c). Characterization of metabolites during biodegradation of (RDX) with municipal anaerobic sludge characterization of metabolites during biodegradation of with municipal anaerobic sludge. Appl. Environ. Microbiol. 66, 2652-2657. doi: 10.1128/AEM.66.6.2652-2657.2000

Hawari, J., Shen, C. F., Guiot, S. R., Greer, C. W., Rho, D., Sunahara, G., et al. (2000b). Bioremediation of highly energetic compounds: a search for remediation technologies. Water Sci. Technol. 42, 385-393.

Heerspink, B. P., Pandey, S., Boukhalfa, H., Ware, D. S., Marina, O., Perkins, G., et al. (2017). Fate and transport of hexahydro-1,3,5-trinitro$1,3,5$-triazine $(\mathrm{RDX})$ and its degradation products in sedimentary and volcanic rocks, Los Alamos, New Mexico. Chemosphere 182, 276-283. doi: 10.1016/j.chemosphere.2017.04.149

Hess, T. F., Renn, T. S., Watts, R. J., and Paszczynski, A. J. (2003). Studies on nitroaromatic compound degradation in modified Fenton reactions by electrospray ionization tandem mass spectrometry (ESI-MS-MS). Analyst 128, 156-160. doi: 10.1039/b209776c

Horowitz, H. M., Jacob, D. J., Amos, H. M., Streets, D. G., and Sunderland, E. M. (2014). Historical mercury releases from commercial products: Global environmental implications. Environ. Sci. Technol. 48, 10242-10250. doi: $10.1021 /$ es501337j

Hundal, L. S., Singh, J., Bier, E. L., Shea, P. J., Comfort, S., and Powers, W. L. (1997). Removal of TNT and RDX from water and soil using iron metal. Environ. Pollut. 97, 55-64. doi: 10.1016/S0269-7491(97)00081-X

Huynh, M. H. V., Hiskey, M. A., Meyer, T. J., and Wetzler, M. (2006). Green primaries: environmentally 45 friendly energetic complexes. Proc. Natl. Acad. Sci. U.S.A. 103, 5409-5412. doi: 10.1073/pnas.0600827103 
Inouye, L. S., Lachance, B., and Gong, P. (2009). "Genotoxicity of explosives," in Ecotoxicology of Explosives, eds G. I. Sunahara, G. R. Lotufo, R. G. Kuperman, and J. Hawari (Boca Raton, FL: Taylor and Francis Group, LLC), 177-210.

Jackson, R. G., Rylott, E. L., Fournier, D., Hawari, J., and Bruce, N. C. (2007). Exploring the biochemical properties and remediation applications of the unusual explosive-degrading P450 system XplA/B. Proc. Natl. Acad. Sci. U.S.A. 104, 16822-16827. doi: 10.1073/pnas.0705110104

James Martin Center for Nonproliferation Studies (2017). Chemical Weapon Munitions Dumped at Sea: An Interactive Map. Available online at: https:// www.nonproliferation.org/chemical-weapon-munitions-dumped-at-sea/ (Accessed: January 31, 2018).

Jameson, S. C. (1975). Toxic effect of the explosive depth charge chemicals from the ship SANKISAN MARU on the coral. Micronesica 11, 109-113.

Jarand, C. W., Chen, K., Pozniak, B., Cole, R. B., Pham, D. T., Lincoln, S. F., et al. (2011). Degradation products of TNT after fenton oxidation in the presence of cyclodextrins. ACS Symp. Ser. 1069, 343-353. doi: 10.1021/bk-2011-1069.ch017

Johnson, L. R., Davenport, R., Balbach, H., and Schaeffer, D. J. (1994). Phototoxicology: 3. Comparative toxicity of trinitrotoluene and aminodinitrotoluenes to Daphnia magna, Dugesia dorotocephala, and sheep erythrocytes. Ecotoxicol. Environ. Saf. 27, 34-49. doi: 10.1006/eesa.1994.1005

Juhasz, A. L., and Naidu, R. (2007). Explosives: fate dynamics, and ecological impact in terrestrial and marine environments. Rev. Env. Contam Toxicol. 191, 163-215. doi: 10.1007/978-0-387-69163-3_6

Jurczak, W., and Fabisiak, J. (2017). Corrosion of ammunition dumped in the Baltic Sea. J. KONBiN 41, 227-246. doi: 10.1515/jok-2017-0012

Kalderis, D., Juhasz, A. L., Boopathy, R., and Comfort, S. (2011). Soils contaminated with explosives: environmental fate and evaluation of state-ofthe-art remediation processes (IUPAC Technical Report). Pure Appl. Chem. 83, 1407-1484. doi: 10.1351/PAC-REP-10-01-05

Kaplan, L. A., Burlinson, N. E., and Sitzman, M. E. (1975). Photochemistry of TNT: investigation of the 'pink water' problem. PART II, AD-AO20 072.

Katseanes, C. K., Chappell, M. A., Hopkins, B. G., Durham, B. D., Price, C. L., Porter, B. E., et al. (2017). Multivariate soil fertility relationships for predicting the environmental persistence of 2,4,6-trinitrotoluene (TNT) and 1,3,5-trinitro-1,3,5-tricyclohexane (RDX) among taxonomically distinct soils. J. Environ. Manage. 203, 383-390. doi: 10.1016/j.jenvman.2017.08.005

Koide, S., Silva, J. A. K., Dupra, V., and Edwards, M. (2016). Bioaccumulation of chemical warfare agents, energetic materials, and metals in deep-sea shrimp from discarded military munitions sites off Pearl Harbor. Deep. Res. Part II Top. Stud. Oceanogr. 128, 53-62. doi: 10.1016/j.dsr2.2015.03.002

Koschinski, S., and Kock, K.-H. (2009). Underwater unexploded ordnance methods for a cetacean-friendly removal of explosives as alternatives to blasting. Reports Int. Whal. Comm. SC/61/E21, 1-13.

Krohn, A. W. (1994). The challenge of dumped ammunition in the Baltic Sea. Hisp. J. Behav. Sci. 25, 93-103. doi: 10.1177/0967010694025001008

Kunz, R. R., Gregory, K. E., Aernecke, M. J., Clark, M. L., Ostrinskaya, A., and Fountain, A. (2012). W. Fate dynamics of environmentally exposed explosive traces. J. Phys. Chem. A 116, 3611-3624. doi: 10.1021/jp211260t

Kyllönen, K., Paatero, J., Aalto, T., and Hakola, H. (2014). Nationwide survey of airborne mercury in Finland. Boreal Environ. Res. 19, 355-367.

Landmine Action (2005). Explosive Remnants of War and Mines Other Than Anti-personnel Mines: Global Survey 2003-2004. p. 196.

Lee, C. K. M., and Stenstrom, M. K. (1996). Competitive Adsorption of Cyclotrimethylenetrinitramine (RDX) and Cyclotetramethylenetetranitramine (HMX), ENG 96-152.

Leggett, D. C. (1985). Sorption of military explosive contaminants on bentonite drilling muds. CRREL Report 85-18. AMX-TH-TE-.

Lenke, H., Achtnich, C., and Knackmuss, H.-J. (2000). "Perspectives of bioelimination of polynitroaromatic compounds," in Biodegradation of Nitroaromatic Compounds and Explosives, eds J. C. Spain, J. B. Hughes, and H.-J. Knackmuss (CRC Press LLC), 91-126.

Lever, J. H., Taylor, S., Perovich, L., Bjella, K., and Packer, B. (2005). Dissolution of composition B detonation residuals. Environ. Sci. Technol. 39, 8803-8811. doi: $10.1021 / \mathrm{es} 050511 \mathrm{r}$

Li, A. Z., Marx, K. A., Walker, J., and Kaplan, D. L. (1997). Trinitrotoluene and metabolites binding to humic acid. Environ. Sci. Technol. 31, 584-589. doi: $10.1021 /$ es 960486 c
Li, S., George, R. D., and Hihara, L. H. (2016). Corrosion analysis and characteristics of discarded military munitions in ocean waters. Corros. Sci. 102, 36-43. doi: 10.1016/j.corsci.2015.09.014

Li, Z. M., Shea, P. J., and Comfort, S. D. (1998). Nitrotoluene destruction by UV-catalyzed fenton oxidation. Chemosphere 36, 1849-1865. doi: 10.1016/S0045-6535(97)10073-X

Liang, S. H., Hsu, D. W., Lin, C. Y., Kao, C. M., Huang, D. J., Chien, C. C., et al. (2017). Enhancement of microbial 2,4,6-trinitrotoluene transformation with increased toxicity by exogenous nutrient amendment. Ecotoxicol. Environ. Saf. 138, 39-46. doi: 10.1016/j.ecoenv.2016.12.012

Liou, M. J., Lu, M. C., and Chen, J. N. (2003). Oxidation of explosives by Fenton and photo-Fenton processes. Water Res. 37, 3172-3179. doi: 10.1016/S0043-1354(03)00158-1

Lisichkin, G. V. (1996). "Chemical weapons on the seabed," in Sea-Dumped Chemical Weapons: Aspects, Problems and Solutions, ed A. V. Kaffka (Dordrecht: Springer-Science+Business Media, B.V.), 121-128.

Lotufo, G. R., and Lydy, M. J. (2005). Comparative toxicokinetics of explosive compounds in sheepshead minnows. Arch. Environ. Contam. Toxicol. 49, 206-214. doi: 10.1007/s00244-004-0197-7

Lotufo, G. R., Belden, J. B., Fisher, J. C., Chen, S. F., Mowery, R. A., Chambliss, C. K., et al. (2016). Accumulation and depuration of trinitrotoluene and related extractable and nonextractable (bound) residues in marine fish and mussels. Environ. Pollut. 210, 129-136. doi: 10.1016/j.envpol.2015.11.049

Lotufo, G. R., Blackburn, W., Marlborough, S. J., and Fleeger, J. W. (2010). Toxicity and bioaccumulation of TNT in marine fish in sediment exposures. Ecotoxicol. Environ. Saf. 73, 1720-1727. doi: 10.1016/j.ecoenv.2010.02.009

Lotufo, G. R., Chappell, M. A., Price, C. L., Ballentine, M. L., Fuentes, A. A., Bridges, T. D., et al. (2017). Review and Synthesis of Evidence Regarding Environmental Risks Posed by Munitions Constituents (MC) in Aquatic Systems. ERDC/EL TR-17-17, SERDP ER-2341.

Lotufo, G. R., Farrar, J. D., Inouye, L. S., Bridges, T. S., and Ringelberg, D. B. (2001). Toxicity of sediment-associated nitroaromatic and cyclonitramine compounds to benthic invertebrates. Environ. Toxicol. Chem. 20, 1762-1771. doi: 10.1002/etc. 5620200820

Lotufo, G. R., Rosen, G., Wild, W., and Carton, G. (2013). Summary Review of the Aquatic Toxicology of Munitions Constituents, ERDC/EL TR-13-R-18.

Love, R., and Pfennig, R. (1951). Aromatics from Petroleum. Adv. Chem. 5, 299-309. doi: 10.1021/ba-1951-0005.ch026

Luning Prak, D. J., and O'Sullivan, D. W. (2006). Solubility of 2,4-Dinitrotoluene and 2,4,6-Trinitrotoluene in Seawater. J. Chem. Eng. Data 51, 448-450. doi: $10.1021 /$ je0503731

Luning Prak, D. J., and O'Sullivan, D. W. (2007). Solubility of 4-nitrotoluene, 2,6dinitrotoluene, 2,3-dinitrotoluene, and 1,3,5-trinitrobenzene in Pure water and seawater. J. Chem. Eng. Data 52, 2446-2450. doi: 10.1021/je700374j

Luning Prak, D. J., Breuer, J. E. T., Rios, E. A., Jedlicka, E. E., and O'Sullivan, D. W. (2017). Photolysis of 2,4,6-trinitrotoluene in seawater and estuary water: Impact of $\mathrm{pH}$, temperature, salinity, and dissolved organic matter. Mar. Pollut. Bull. 114, 977-986. doi: 10.1016/j.marpolbul.2016.10.073

Luning Prak, D. J., Milewski, E. A., Jedlicka, E. E., Kersey, A. J., and O'Sullivan, D. W. (2013). Influence of $\mathrm{pH}$, temperature, salinity, and dissolved organic matter on the photolysis of 2,4-dinitrotoluene and 2,6-dinitrotoluene in seawater. Mar. Chem. 157, 233-241. doi: 10.1016/j.marchem.2013.10.009

Lynch, J. C. (2002). Dissolution Kinetics of High Explosive Compounds (TNT, RDX, HMX). US Army Corps of Engineers, Report ERDC/EL TR-02-23. p. 133.

Lynch, J. C., Brannon, J. M., and Delfino, J. J. (2002). Dissolution rates of three high explosive compounds: TNT, RDX, and HMX. Chemosphere 47, 725-734. doi: 10.1016/S0045-6535(02)00035-8

Lynch, J. C., Myers, K. F., Brannon, J. M., and Delfino, J. J. (2001). Effects of $\mathrm{pH}$ and temperature on the aqueous solubility and dissolution rate of 2,4,6-trinitrotoluene (TNT), Hexahydro-1,3,5-trinitro-1,3,5-triazine (RDX), and Octahydro-1,3,5,7-tetranitro-1,3,5,7-tetrazocine (HMX). J. Chem. Eng. Data 46, 1549-1555. doi: 10.1021/je0101496

MEDEA (1997). Ocean dumping of chemical munitions: environmental effects in Arctic seas. 1-231.

Mabey, W. R., Tse, D., Baraze, A., and Mill, T. (1983). Photolysis of nitroaromatics in aquatic systems. I. 2,4,6-trinitrotoluene. Chemosphere 12, 3-16. doi: 10.1016/0045-6535(83)90174-1 
MacLeod, I. D. (2016). In-situ corrosion measurements of WWII shipwrecks in chuuk lagoon, quantification of decay mechanisms and rates of deterioration. Front. Mar. Sci. 3:38. doi: 10.3389/fmars.2016. 00038

Malyshev, L. P. (1996). "Technological questions of safe elimination of CW dumps on the baltic sea bed," in Sea-Dumped Chemical Weapons: Aspects, Problems and Solutions, ed A. V. Kaffka (Dordrecht: Springer- Science+Business Media, B.V.), 93-104.

Martel, R., Mailloux, M., Gabriel, U., Lefebvre, R., Thiboutot, S., and Ampleman, G. (2009). Behavior of energetic materials in ground water at an anti-tank range. J. Environ. Qual. 38:75. doi: 10.2134/jeq2007.0606

Matyáš, R., and Pachman, J. (2012). Primary explosives. Prim. Explos (Berlin: Springer-Verlag), 1-338. doi: 10.1007/978-3-642-28436-6_2

McCormick, N. G., Cornell, J. H., and Kaplan, A. M. (1981). Biodegradation of Hexahydro-1,3,5-Trinitro-1,3,5-Triazine. Appl. Environ. Microbiol. 42, 817-823.

McCormick, N. G., Cornell, J. H., and Kaplan, A. M. (1984). The Anaerobic Biotransformation of RDX, HMX, and Their Acetylated Derivatives. UNITED STATES ARMY NATICK RESEARCH \& DEVELOPMENT CENTER, Report NATICK/TR-85/007.

McDonald, J. (2009). Demonstration of the Marine Towed Array on Bahia Salinas del Sur Vieques. Puerto Rico: Environmental Security Technology Certification Program. doi: 10.21236/ADA520620

McLellan, W. L., Hartley, W. R., and Brower, M. E. (1988). Health Advisory for Octahydro-l,3,5,7-Tetranitro-l,3,5,7-Tetrazocine (HMX). Washington, DC: U.S. Environmental Protection Agency.

Mihas, O., Kalogerakis, N., and Psillakis, E. (2007). Photolysis of 2,4-dinitrotoluene in various water solutions: effect of dissolved species. J. Hazard. Mater. 146, 535-539. doi: 10.1016/j.jhazmat.2007.04.054

Mills, A., Seth, A., and Peters, G. (2003). Alkaline hydrolysis of trinitrotoluene, TNT. Phys. Chem. Chem. Phys. 5:3921. doi: 10.1039/b304616h

Missiaen, T., and Henriet, J. P. (2002). "Chemical munition dump sites in coastal environments: a border-transgressing problem," in Chemical Munition Dump Sites in Coastal Environments, eds T. Missiaen, and J. P. Henriet (Brussels: Federal Office for Scientific, Technical and Cultural Affairs (OSTC), Federal Ministry of Social Affairs, Public Health and the Environment), 1-12.

Missiaen, T., and Feller, P. (2008). Very-high-resolution seismic and magnetic investigations of a chemical munition dumpsite in the Baltic Sea. J. Appl. Geophys. 65, 142-154. doi: 10.1016/j.jappgeo.2008.07.001

Monahan, P. (2016). World War II, Opium Wars recorded in ocean's corals. Sci. Mag. 5. doi: 10.1126/science.aag0583

Monfils, R., Gilbert, T., and Nawadra, S. (2006). Sunken WWII shipwrecks of the Pacific and East Asia: the need for regional collaboration to address the potential marine pollution threat. Ocean Coast. Manag. 49, 779-788. doi: 10.1016/j.ocecoaman.2006.06.011

Monteil-Rivera, F., Halasz, A., Groom, C., Zhao, J.-S., Thiboutot, S., Ampleman, G., et al. (2009). "Fate and transport of explosives in the environment: a chemist's view," in Ecotoxicology of Explosives and Unexploded Ordnance, eds G. Sunahara, G. Lutofo, R. Kuperman, and J. Hawari (Boca Raton, FL: CRC Press, Taylor and Francis Group LLC), 5-33.

Monteil-Rivera, F., Paquet, L., Deschamps, S., Balakrishnan, V. K., Beaulieu, C., and Hawari, J. (2004). Physico-chemical measurements of CL-20 for environmental applications: comparison with RDX and HMX. J. Chromatogr. A 1025, 125-132. doi: 10.1016/j.chroma.2003.08.060

Monteil-Rivera, F., Paquet, L., Giroux, R., and Hawari, J. (2008). Contribution of hydrolysis in the abiotic attenuation of RDX and HMX in coastal waters. J. Environ. Qual. 37, 858-864. doi: 10.2134/jeq2007.0451

Montgomery, M. T., Boyd, T. J., Coffin, R. B., Drake, L. A., Hansen, L. T., and Osburn, C. L. (2014). TNT Degradation by Natural Microbial Assemblages at Frontal Boundaries Between Water Masses in Coastal Ecosystems. (ER-2124 Interim Report), 33.

Montgomery, M. T., Boyd, T. J., Smith, J. P., Walker, S. E., and Osburn, C. L. (2011b). 2,4,6-“Trinitrotoluene mineralization and incorporation by natural bacterial assemblages in coastal ecosystems," in Environmental Chemistry of Explosives and Propellant Compounds in Soils and Marine Systems: Distributed Source Characterization and Remedial Technologies, ACS symposium series, eds M. A. Chappell, C. L. Price, and R. D. George, Washington, DC: American Chemical Society, 171-184.
Montgomery, M. T., Coffin, R. B., Boyd, T. J., and Osburn, C. L. (2013). Incorporation and mineralization of TNT and other anthropogenic organics by natural microbial assemblages from a small, tropical estuary. Environ. Pollut. 174, 257-264. doi: 10.1016/j.envpol.2012.11.036

Montgomery, M. T., Coffin, R. B., Boyd, T. J., Smith, J. P., Walker, S. E., and Osburn, C. L. (2011a). 2,4,6-Trinitrotoluene mineralization and bacterial production rates of natural microbial assemblages from coastal sediments. Environ. Pollut. 159, 3673-3680. doi: 10.1016/j.envpol.2011. 07.018

Morley, M. C., Yamamoto, H., Speitel, G. E., and Clausen, J. (2006). Dissolution kinetics of high explosives particles in a saturated sandy soil. J. Contam. Hydrol. 85, 141-158. doi: 10.1016/j.jconhyd.2006.01.003

Nadim, F., Bagtzoglou, A. C., and Iranmahboob, J. (2008). Coastal management in the Persian Gulf region within the framework of the ROPME programme of action. Ocean Coast. Manag. 51, 556-565. doi: 10.1016/j.ocecoaman.2008.04.007

National Geospatial-Intelligence Agency (2017). Red sea and the persian gulf. Pub. Sail. Dir. 454.

NATO (2010). Environmental Impact of Munition and Propellant Disposal. TRAVT-115.

Nehring, S. (2005). Rüstungsaltlasten in den deutschen Küstengewässern Handlungsempfehlungen zur erfolgreichen Umsetzung der EuropäischenWasserrahmenrichtlinie. Rostock. Meeresbiolog. Beitr. 14, 109-123.

Nipper, M., Carr, R. S., and Lotufo, G. R. (2009). “Aquatic toxicology of explosives," in Ecotoxicology of Explosives, eds G. I. Sunahara, G. Lotufo, R.G. Kuperman, J. Hawari (Boca Raton, FL: CRC Press, Taylor and Francis Group LLC), 77-115.

Nipper, M., Carr, R. S., Biedenbach, J. M., Hooten, R. L., Miller, K., and Saepoff, S. (2001). Development of marine toxicity data for ordnance compounds. Arch. Environ. Contam. Toxicol. 41, 308-318. doi: 10.1007/s002440010253

Nipper, M., Qian, Y., Carr, R. S., and Miller, K. (2004). Degradation of picric acid and 2,6-DNT in marine sediments and waters: the role of microbial activity and ultra-violet exposure. Chemosphere 56, 519-530. doi: 10.1016/j.chemosphere.2004.04.039

Nixon, E. (2009). Assessment of the Impact of Dumped Conventional and Chemical Munitions. OSPAR Commis. 1-23.

NOAA and Ridolfi (2006). Final Data Report For The Vieques Island Biota Sampling Project.

O’Sullivan, D. W., Denzel, J. R., and Luning Prak, D. J. (2011). "Photolysis of 2,4,6-trinitrotoluene in seawater: effect of salinity and nitrate concentration," in Environmental Chemistry of Explosives and Propellant Compounds in Soils and Marine Systems: Distributed Source Characterization and Remedial Technologies, ACS Symposium Series (Washington, DC: American Chemical Society), 157-169. doi: 10.1021/bk-2011-1069.ch008

Obhodas, J., Valkovic, V., Sudac, D., Matika, D., Pavic, I., and Kollar, R. (2010). Environmental security of the coastal seafloor in the sea ports and waterways of the Mediterranean region. Nucl. Instruments Methods Phys. Res. Sect. A Accel. Spectrometers, Detect. Assoc. Equip. 619, 419-426. doi: 10.1016/j.nima.2010.02.277

Oh, S. Y., Chiu, P. C., Kim, B. J., and Cha, D. K. (2003). Enhancing Fenton oxidation of TNT and RDX through pretreatment with zero-valent iron. Water Res. 37, 4275-4283. doi: 10.1016/S0043-1354(03)00343-9

Overfield, M. L., and Symons, L. C. (2009). The use of the RUST database to inventory, monitor, and assess risk from undersea threats. Mar. Technol. Soc. J. 43, 33-40. doi: 10.4031/MTSJ.43.4.9

Ownby, D. R., Belden, J. B., Lotufo, G. R., and Lydy, M. J. (2005). Accumulation of trinitrotoluene (TNT) in aquatic organisms: part 1 - Bioconcentration and distribution in channel catfish (Ictalurus punctatus). Chemosphere 58, 1153-1159. doi: 10.1016/j.chemosphere.2004.09.059

Oyler, K. D., Meta, N., and Chen, G. (2015). Overview of Explosive Initiators. (Picatinny Arsenal, NJ: Army Armament Research Development and Engineering Center), 24. doi: 10.21236/ADA625185

Paquet, L., Monteil-Rivera, F., Hatzinger, P. B., Fuller, M. E., and Hawari, J. (2011). Analysis of the key intermediates of RDX (hexahydro-1,3,5-trinitro-1,3,5triazine) in groundwater: occurrence, stability and preservation. J. Environ. Monit. 13, 2304-2311. doi: 10.1039/clem10329f

Pennington, J. C., and Patrick, W. Jr. (1990). Adsorption and Desorption of 2,4,6Trinitrotoluene by Soils. US Army Engineer Waterways Experiment Station, Report Ad-A189 719. p. 36 
Pennington, J. C., Hayes, C. A., Myers, K. F., Ochman, M., Gunnison, D., Felt, D. R., et al. (1995). Fate of 2,4,6-trinitrotoluene in a simulated compost system. Chemosphere 30, 429-438. doi: 10.1016/0045-6535(94)00422-Q

Pennington, J. C., Lotufo, G., Hayes, C. A., Porter, B., and George, R. D. (2011). TNT, RDX, and HMX association with organic fractions of marine sediments and bioavailability implications. ACS Symp. Ser. 1069, 185-195. doi: 10.1021/bk-2011-1069.ch010

Pfeiffer, F. (2009). Bericht über die in-situ-Begleituntersuchungen zur Munitionssprengung in der Ostsee vom 18.2.2009.

Pfeiffer, F. (2012a). Changes in properties of explosives due to prolonged seawater exposure. Mar. Technol. Soc. J. 46, 102-110. doi: 10.4031/MTSJ.46.1.5

Pfeiffer, F. (2012b). Bericht über die in-situ-Begleituntersuchungen zur Munitionssprengung in der Ostsee vom 28.2. - 18.3.2012.

Phelan, J. M., and Barnett, J. L. (2001). Solubility of 2,4-Dinitrotoluene and 2,4,6-Trinitrotoluene in Water. J. Chem. Eng. Data 46, 375-376. doi: $10.1021 /$ je000300w

Phelan, J. M., Romero, J. V., Barnett, J. L., and Parker, D. R. (2002). Solubility and Dissolution Kinetics of Composition B Explosive in Water. Livermore, CO; Albuquerque, NM: Sandia National Labs. doi: 10.2172/801397

Plunkett, G. (2003). Chemical Warfare Agent Sea Dumping off Australia. (United States Department of Defense), 44.

Porter, J. W., Barton, J. V., and Torres, C. (2011). "Ecological, radiological, and toxicological effects of naval bombardment on the coral reefs of Isla de Vieques, Puerto Rico," in Warfare Ecology: A New Synthesis for Peace and Security, eds G. E. Machlis, T. Hanson, Z. Špirić, and J. E. McKendry (Dordrecht: Springer Netherlands), 65-122.

Preuss, A., Fimpel, J., and Diekert, G. (1993). Anaerobic transformation of 2,4,6trinitrotoluene (TNT). Arch. Microbiol. 159, 345-353. doi: 10.1007/BF00290917

Price, C. B., Brannon, J. M., Yost, S. L., and Hayes, C. A. (2000). Adsorption and Transformation of RDX in Low-carbon Aquifer Soils, ERDC/EL TR-00-11.

Qian, J. G., Mopper, K., and Kieber, D. J. (2001). Photochemical production of the hydroxyl radical in Antarctic waters. Deep. Res. Part I Oceanogr. Res. Pap. 48, 741-759. doi: 10.1016/S0967-0637(00)00068-6

Rapp-Wright, H., McEneff, G., Murphy, B., Gamble, S., Morgan, R., Beardah, M., et al. (2017). Suspect screening and quantification of trace organic explosives in wastewater using solid phase extraction and liquid chromatographyhigh resolution accurate mass spectrometry. J. Hazard. Mater. 329, 11-21. doi: 10.1016/j.jhazmat.2017.01.008

Rieger, P., Sinnwell, V., Preuss, A., Francke, W., and Knackmuss, H. (1999). Hydride-meisenheimer complex formation and protonation as key reactions of hydride-meisenheimer complex formation and protonation as key reactions of 2, 4, 6-trinitrophenol biodegradation by rhodococcus erythropolis. J. Bacteriol. $181,1189-1195$.

Ro, K. S., Venugopal, A., Adrian, D. D., Constant, D., Qaisi, K., Valsaraj, K. T., et al. (1996). Solubility of 2,4,6-Trinitrotoluene (TNT) in Water. J. Chem. Eng. Data 41, 758-761. doi: 10.1021/je950322w

Rodacy, P. J., Reber, S. D., and Walker, P. K. (2001). Chemical Sensing of Explosive Targets in the Bedford Basin. (Albuquerque, NM: Sandia National Labs.). doi: 10.2172/789594

Roh, H., Yu, C., Fuller, M. E., and Chu, K.-H. (2009). Identification of Hexahydro1,3,5- trinitro-1,3,5-triazine-Degrading Microorganisms via $15 \mathrm{~N}$-Stable Isotope Probing. Environ. Sci. Technol. 43, 2505-2511. doi: 10.1021/es802336c

Rosen, G., and Lotufo, G. R. (2005). Toxicity and fate of two munitions constituents in spiked sediment exposures with the marine amphipod Eohaustorius estuarius. Environ. Toxicol. Chem. 24, 2887-2897. doi: 10.1897/04-611R.1

Rosen, G., and Lotufo, G. R. (2007). Toxicity of explosive compounds to the marine mussel, Mytilus galloprovincialis, in aqueous exposures. Ecotoxicol. Environ. Saf. 68, 228-236. doi: 10.1016/j.ecoenv.2007.03.006

Rosen, G., and Lotufo, G. R. (2010). Fate and effects of composition b in multispecies marine exposures. Environ. Toxicol. Chem. 29, 1330-1337. doi: $10.1002 /$ etc. 153

Rosenblatt, D. H., Burrows, E. P., Mitchell, W. R., and Parmer, D. L. (1989). "Organic explosives and related compounds," in The Handbook of Environmental Chemistry, ed O. Hutzinger (Fort Detrick, MD: Army Biomedical Research and Develoment Lab), 195-234.

Rossland, H. K., Johnsen, A., Karsrud, T. E., Parmer, M. P., Larsen, A., Myran, A., et al. (2010). Forurensning fra Ammunisjon i Akvatisk Miljø og på Kystfort
-Innledende Undersøkelser. Forsvarets forskningsinstitutt (FFI), Report FFIrapport 2010/00239. p. 87.

Royal New Zealand Navy (2015). "Ammunition dumping in the waters around New Zealand," in Annual NZ Notices to Mariners: New Zealand Nautical Almanac.

Sæbø, T. O., Hansen, R. E., and Lorentzen, O. J. (2015). Using an interferometric synthetic aperture sonar to inspect the Skagerrak World War II chemical munitions dump site. Ocean 2015 - MTS/IEEE Washingt. 1-10. doi: 10.23919/OCEANS.2015.7401927

Samuel, L. B., and Herbert, J. E. (2007). "Special session: AUVs: groundtruthing high-resolution AUV side scan sonar contacts for unexploded ordnance in a deepwater geohazard assessment (OTC 18844)," in Proceedings of the Offshore Technology Conference (Houston, TX), 14.

Sanderson, H., and Fauser, P. (2015). Environmental Assessments of Sea Dumped Chemical Warfare Agents: CWA Report. Danish Centre for Environment and Energy.

Sanderson, H., Fauser, P., Rahbek, M., and Larsen, J. (2014). B. Review of environmental exposure concentrations of chemical warfare agent residues and associated the fish community risk following the construction and completion of the nord stream gas pipeline between Russia and Germany. J. Hazard. Mater. 279, 518-526. doi: 10.1016/j.jhazmat.2014.06.073

Sanderson, H., Fauser, P., Stauber, R. S., Christensen, J., Løfstrøm, P., and Becker, T. (2017). Civilian exposure to munition specific carcinogens and resulting cancer risks for civilians on the Puerto Rican island of Vieques following military exercises from 1947-1998. Glob. Secur. Heal. Sci. Policy 2, 40-61. doi: 10.1080/23779497.2017.1369358

Santos, I. R., Eyre, B. D., and Huettel, M. (2012). The driving forces of porewater and groundwater flow in permeable coastal sediments: a review. Estuar. Coast. Shelf Sci. 98, 1-15. doi: 10.1016/j.ecss.2011.10.024

Schmelling, D. C., and Gray, K. A. (1995). Photocatalytic transformation and mineralization of 2,4,6-trinitrotoluene (TNT) in TiO2 slurries. Water Res. 29, 2651-2662. doi: 10.1016/0043-1354(95)00136-9

Schmidt, A., and Butte, W. (1999). Photocatalytic degradation of reduction products of 2,4,6-trinitrotoluene (TNT). Chemosphere 38, 1293-1298. doi: 10.1016/S0045-6535(98)00530-X

Schultz, G., Keranen, J., Gleason, A. C. R., and Gracias, N. (2016). “Littoral seafloor sensing and characterization using marine electromagnetics, optical imagery, and remotely and autonomously operated platforms," in Ocean 2015 MTS/IEEE Washingt.

Schuster, P. F., Krabbenhoft, D. P., Naftz, D. L., Cecil, L. D., Olson, M. L., Dewild, J. F., et al. (2002). Atmospheric mercury deposition during the last 270 years: a glacial ice core record of natural and anthropogenic sources. Environ. Sci. Technol. 36, 2303-2310. doi: 10.1021/es0157503

Sharma, P., Mayes, M. A., and Tang, G. (2013). Role of soil organic carbon and colloids in sorption and transport of TNT, RDX and HMX in training range soils. Chemosphere 92, 993-1000. doi: 10.1016/j.chemosphere.2013.03.028

Sheremata, T. W., Halasz, A., Paquet, L., Thiboutot, S., Ampleman, G., and Hawari, J. (2001). The fate of the cyclic nitramine explosive RDX in natural soil. Environ. Sci. Technol. 35, 1037-1040. doi: 10.1021/es001389t

Sheremata, T. W., Thiboutot, S., Ampleman, G., Paquet, L., Halasz, A., and Hawari, J. (1999). Fate of 2,4,6-trinitrotoluene and its metabolites in natural and model soil systems. Environ. Sci. Technol. 33, 4002-4008. doi: 10.1021/es9901011

Shihavuddin, A. S. M., Gracias, N., Garcia, R., Campos, R., Gleason, A. C. R., and Gintert, B. (2014). Automated detection of underwater military using fusion of 2D and 2.5D features from optical imagery. Mar. Technol. Soc. J. 48, 61-71. doi: 10.4031/MTSJ.48.4.7

Sikka, H. C., Banerjee, S., Pack, E. J., and Appelton, H. T. (1980). Environmental Fate of RDX and TNT. Technical Report 81538.

Silva, J. A. K., and Chock, T. (2016). Munitions integrity and corrosion features observed during the HUMMA deep-sea munitions disposal site investigations. Deep. Res. Part II Top. Stud. Oceanogr. 128, 14-24. doi: 10.1016/j.dsr2.2015.09.001

Simmons, C. C., Carvalho-Knighton, K. M., and Pyrtle, A. J. (2007). "Small scale characterization of the presence of the explosive octahydro-1, 3, 5, 7-tetranitro1, 3, 5, 7 tetrazocine (HMX) near former naval sites on Vieques Island, Puerto Rico," in AGU Fall Meeting Abstracts (San Francisco, CA), 409.

Singh, N., Berns, A. E., Hennecke, D., Hoerner, J., Koerdel, W., and Schaeffer, A. (2010). Effect of soil organic matter chemistry on sorption 
of trinitrotoluene and 2,4-dinitrotoluene. J. Hazard. Mater. 173, 343-348. doi: 10.1016/j.jhazmat.2009.08.090

Sisco, E., Najarro, M., Bridge, C., and Aranda, R. (2015). Quantifying the degradation of TNT and RDX in a saline environment with and without UVexposure. Forensic Sci. Int. 251, 124-131. doi: 10.1016/j.forsciint.2015.04.002

Smit, K. J. (1991). Ultraviolet and visible absorption spectroscopy of some energetic molecules in the solid state. J. Energ. Mater. 9, 81-103. doi: 10.1080/07370659108019859

Smith, R. W., Tobias, C., Vlahos, P., Cooper, C., Ballentine, M. L., Ariyarathna, T., et al. (2015b). Mineralization of RDX-derived nitrogen to N2 via denitrification in coastal marine sediments. Environ. Sci. Technol. 49, 2180-2187. doi: 10.1021/es505074v

Smith, R. W., Vlahos, P., Böhlke, J. K., Ariyarathna, T., Ballentine, M. L., Cooper, C., et al. (2015a). Tracing the cycling and fate of the explosive 2,4,6trinitrotoluene in coastal marine systems with a stable isotopic tracer, $15 \mathrm{~N}$ [TNT]. Environ. Sci. Technol. 49, 12223-12231. doi: 10.1021/acs.est.5b02907

Southworth, B. A. (2002). Hydroxyl Radical Production via the Photo-Fenton Reaction in Natural Waters. Cambridge, MA: Massachusetts Institute of Technology.

Spain, J. (1995). Biodegradation of nitroaromatic compounds. Annu. Rev. Microbiol. 49, 523-555. doi: 10.1146/annurev.mi.49.100195.002515

Spalding, R. F., and Fulton, J. W. (1988). Groundwater munition residues and nitrate near grand Island, Nebraska, U.S.A. J. Contam. Hydrol. 2, 139-153. doi: 10.1016/0169-7722(88)90004-6

Spanggord, R. J., Mabey, R. W., Chou, T. W., Haynes, D. L., Alfernese, P. L., Tse, D. S., et al. (1982). Environmental Fate Studies of HMX, Screening Studies. Final report, Phase I - Laboratory study 51 (LSU-4412). doi: 10.21236/ADA 148978

Spanggord, R. J., Malbey, W. R., Mill, T., Chou, T.-W., Smith, J. H., Lee, S., et al. (1983). Environmental Fate Studies on Certain Munitions Wastewater Constituents Phase IV - Lagoon Model Studies. U.S. ARMY MEDICAL RESEARCH AND DEVELOPMENT COMMAND. Report ADA138550. p. 159.

Spanggord, R. J., Mill, T., Chou, T.-W., Mabey, W. R., Lee, S., and Smith, J. H. (1980). Environmental Fate Studies on Certain Munition Wastewater Constituents. U.S. Army Medical Research and Development Command. Report ADA099256. p. 209.

Spain, J. C., Hughes, J. B., and Knackmuss, H.-J. (eds.). (2000). Biodegradation of Nitroaromatic Compounds and Explosives. (Boca Raton, FL: CRC Press LLC), 451.

Speight, J. G. (2011). Handbook of Industrial Hydrocarbon Processes. Burlington, MA: Gulf Professional Publishing.

Srinivasan, R., and Hihara, L. H. (2016). "Galvanic corrosion evaluation of discarded military munition steel casing and copper driving bands in seawater," in ECS Meeting Abstracts MA2016-02. Honolulu, HI.

Stauffer, M., Pignolet, A., and Corcho Alvarado, J. A. (2017). Persistent mercury contamination in shooting range soils: the legacy from former primers. Bull. Environ. Contam. Toxicol. 98, 14-21. doi: 10.1007/s00128-016-1976-3

Sun, R., Hintelmann, H., Liu, Y., Li, X., and Dimock, B. (2016). Two centuries of coral skeletons from the Northern South China Sea record mercury emissions from modern Chinese wars. Environ. Sci. Technol. 50, 5481-5488. doi: 10.1021/acs.est.5b05965

Surikov, B. T. (1996). "How to save the baltics from ecological disaster," in SeaDumped Chemical Weapons: Aspects, Problems and Solutions, ed A. V. Kaffka (Dordrecht: Springer-Science+Business Media, B.V.), 67-70.

Symons, Z. C., and Bruce, N. C. (2006). Bacterial pathways for degradation of nitroaromatics. Nat. Prod. Rep. 23, 845-850. doi: 10.1039/b502796a

Szecsody, J. E., Comfort, S., Fredrickson, H. L., Riley, R. E., Crocker, F., Shea, P., et al. (2014). In situ degradation and remediation of energetics TNT, RDX, HMX, and CL-20 and a byproduct NDMA in the sub-surface environment," in Biological Remediation of Explosive Residues, ed S. N. Singh (Dordrecht: Springer International Publishing), 313-370.

Talmage, S. S., Opresko, D. M., Maxwell, C. J., Welsh, C. J., Cretella, F. M., Reno, P. H., et al. (1999). Nitroaromatic munition compounds: environmental effects and screening values. Rev. Environ. Contam. Toxicol. 161, 1-156. doi: 10.1007/978-1-4757-6427-7_1

Taylor, C. A., and Rinkenbach, W. H. (1923). The solubility of trinitrotoluene in organic solvents. J. Am. Chem. Soc. 45, 44-59. doi: 10.1021/ja01654a006
Taylor, S., Lever, J. H., Fadden, J., Perron, N., and Packer, B. (2009). Outdoor weathering and dissolution of TNT and Tritonal. Chemosphere 77, 1338-1345. doi: 10.1016/j.chemosphere.2009.09.040

Taylor, S., Lever, J., Walsh, M., Fadden, J., Perron, N., Bigl, S., et al. (2010). Dissolution Rate, Weathering Mechanics, and Friability of TNT, Comp B, Tritonal, and Octol, ERDC/CRRELL TR-10-R-12.

Thiboutot, S., Ampleman, G., Gagnon, A., Marois, A., Jenkins, T. F., Walsh, M. E., et al. (1998). Characterization of Antitank Firing Ranges At CFB Valcartier, WATCWainwright And CFAD Dundurn. Report DREV - R - 9809. p. 67.

Thiel, H. (2003). Anthropogenic impacts on the deep sea. Ecosyst. World 427-471.

Thorn, K., and Kennedy, K. R. (2002). 15 N NMR investigation of the covalent binding of reduced TNT amines to soil humic acid, model compounds, and lignocellulose. Environ. Sci. Technol. 36, 3787-3796. doi: 10.1021/es01 $1383 j$

Thorne, P. G., and Leggett, D. C. (1997). Hydrolytic release of bound residues from composted soil. Environ. Toxicol. Chem. 16, 1132-1134.

Tornero, V., and Hanke, G. (2016). Chemical contaminants entering the marine environment from sea-based sources: a review with a focus on European seas. Mar. Pollut. Bull. 112, 17-38. doi: 10.1016/j.marpolbul.2016.06.091

Travis, A. S. (2015). The Synthetic Nitrogen Industry in World War I: Its Emergence and Expansion. Springer, 163.

UNEP/MAP (2009). Ammunitions Dumping sites in the Mediterranean Sea (UNEP(DEPI)/MED WG. 338/2). Athens: United Nations Environment Programme.

US ARMY (2001). Offshore Disposal of Chemical and Conventional Weapons Conducted by the United States. Historical Research and Response Team, US Army Research, Development, and Engineering Command. Historical Database No. 26. p. 16.

United Nations General Assembly (2013). Cooperative Measures to Assess and Increase Awareness of Environmental Effects Related to Waste Originating From Chemical Munitions Dumped at Sea. A/68/258.

United Nations. (2017). Progress Towards the Sustainable Development Goals: Report of the Secretary-General (E/2017/66). Economic and Social Council. p. 19.

US EPA (2012). EPA Federal Facilities Forum Issue Paper: Site Characterization For Munitions Constituents. EPA-505-S-11-001.

Valkovic, V., Matika, D., Kollar, R., Obhodas, J., and Sudac, D. (2009). "Environmental security of the adriatic coastal sea floor," in International Conference on Advancements in Nuclear Instrumentation Measurement Methods and Their Applications (Orlando, FL), 1-8.

Van Aken, B., Yoon, J. M., Just, C. L., and Schnoor, J. L. (2004). Metabolism and mineralization of inside poplar tissues (populus deltoides $\times$ nigra DN-34). Environ. Sci. Technol. 38, 4572-4579. doi: 10.1021/es049837a

Völker, B. M., Morel, F. M. M., and Sulzberger, B. (1997). Iron redox cycling in surface waters: effects of humic substanes and light. Environ. Sci. Technol. 31, 1004-1011. doi: 10.1021/es9604018

Walker, S. W., Osburn, C. L., Boyd, T. J., Hamdan, L. J., Coffin, R. B., Montgomery, M. T., et al. (2006). Mineralization of 2,4,6-Trinitrotoluene (TNT) in Coastal Waters and Sediments.

Wang, P.-F., George, R. D., Wild, W., and Liao, Q. (2013). Defining Munition Constituent (MC) Source Terms in Aquatic Environments on DoD Ranges (ER-1453). SSC Pacific Technical Report 1999. 130 pp.

Wang, P.-F., Liao, Q., George, R., and Wild, W. (2011). Release rate and transport of munitions constituents from breached shells in marine environment. ACS Symp. Ser. 1069, 317-340. doi: 10.1021/bk-2011-1069.ch016

Weissmahr, K. W., Haderlein, S. B., and Schwarzenbach, R. P. (1998). Complex formation of soil minerals with nitroaromatic explosives and other pi-acceptors. Soil Sci. Soc. Am. J. 62, 369-378. doi: 10.2136/sssaj1998.03615995006200020012x

Weissmahr, K. W., Hildenbrand, M., Schwarzenbach, R. P., and Haderlein, S. B. (1999). Laboratory and field scale evaluation of geochemical controls on groundwater transport of nitroaromatic ammunition residues. Environ. Sci. Technol. 33, 2593-2600. doi: 10.1021/es981107d

Wessel, P., and Smith, W. H. F. (2017). Global Self-consistent Hierarchical Highresolution Geography, GSHHG, Version 2.3.7. Available online at: www.gebco. net

White, E. M., Vaughan, P. P., and Zepp, R. G. (2003). Role of the photo-Fenton reaction in the production of hydroxyl radicals and photobleaching of colored 
dissolved organic matter in a coastal river of the southeastern United States. Aquat. Sci. 65, 402-414. doi: 10.1007/s00027-003-0675-4

Wichert, U. (2010). "Problems in Locating Historic Dumping Sites," in Presentation: International Conference on Minimizing Risks for the Environment in Marine Ammunition Removal in the Baltic and North Sea (MIREMAR) (Neumünster).

Wichert, U. (2018). Personal Communication.

Wijker, R. S., Bolotin, J., Nishino, S. F., and Hofstetter, T. B. (2013). Using compound-specific isotope analysis to assess biodegradation of nitroaromatic explosives in the subsurface. Environ. Sci. Technol. 47, 6872-6883. doi: 10.1021/es3051845

Wilbrand, J. (1863). Notiz über Trinitrotoluol. Justus Liebigs Ann. Chem. 128, 178-179. doi: 10.1002/jlac.18631280206

Williams, A. (2016). New technology could help reduce UXO survey costs. Offshore Wind J. 5, 40-41.

Williams, R. E., Rathbone, D. A., Scrutton, N. S., and Bruce, N. C. (2004). Biotransformation of explosives by the old yellow enzyme family of flavoproteins. Appl. Environ. Microbiol. 70, 3566-3574. doi: 10.1128/AEM.70.6.3566-3574.2004

Wittich, R. M., Haïdour, A., Van Dillewijn, P., and Ramos, J. L. (2008). OYE flavoprotein reductases initiate the condensation of TNT-derived intermediates to secondary diarylamines and nitrite. Environ. Sci. Technol. 42, 734-739. doi: 10.1021/es071449w

Wittich, R. M., Ramos, J. L., and Van Dillewijn, P. (2009). Microorganisms and explosives: Mechanisms of nitrogen release from TNT for use as an n-source for growth. Environ. Sci. Technol. 43, 2773-2776. doi: 10.1021/es803372n

Won, W. D., DiSalvo, L. H., and Ng, J. (1976). Toxicity and mutagenicity of 2,4,6-trinitrotoluene and its microbial metabolites. Appl. Environ. Microbiol.31, 576-580.

Woodley, C., and Downs, C. (2014). Ecological Risk Assessment of Munitions Compounds on Coral and Coral Reef Health, SERDP Project ER-2125.

Wozniak, B., and Dera, J. (2007). Light Absorption in Sea Water, Vol. 33. New York, NY: Springer Science and Business Media.

Xu, X., Koeberg, M., Kuijpers, C. J., and Kok, E. (2014). Development and validation of highly selective screening and confirmatory methods for the qualitative forensic analysis of organic explosive compounds with high performance liquid chromatography coupled with (photodiode array and) LTQ ion trap/Orbitrap ma. Sci. Justice, 54, 3-21. doi: 10.1016/j.scijus.2013.08.003

Yamamoto, H., Morley, M., Speitel, G., and Clausen, J. (2004). Fate and transport of high explosives in a sandy soil: adsorption and desorption. Soil Sediment Contam. 13, 361-379. doi: 10.1080/10588330490500419
Yardin, G., and Chiron, S. (2006). Photo-Fenton treatment of TNT contaminated soil extract solutions obtained by soil flushing with cyclodextrin. Chemosphere 62, 1395-1402. doi: 10.1016/j.chemosphere.2005. 05.019

Yinon, J. (1982). Mass spectrometry of explosives: Nitro compounds, nitrate esters, and nitramines. Mass Spectrom. Rev. 1, 257-307. doi: 10.1002/mas.12800 10304

Zhang, D., Zhu, D., and Chen, W. (2009). Sorption of nitroaromatics to soils: Comparison of the importance of soil organic matter versus clay. Environ. Toxicol. Chem. 28, 1447-1454. doi: 10.1897/08-406.1

Zhao, J.-S., Greer, C. W., Thiboutot, S., Ampleman, G., and Hawari, J. (2004). Biodegradation of the nitramine explosives hexahydro-1,3,5-trinitro-1,3,5triazine and octahydro-1,3,5,7-tetranitro-1,3,5,7-tetrazocine in cold marine sediment under anaerobic and oligotrophic conditions. Can. J. Microbiol. 50, 91-96. doi: 10.1139/w03-112

Zheng, W., Lichwa, J., D'Alessio, M., and Ray, C. (2009). Fate and transport of TNT, RDX, and HMX in streambed sediments: Implications for riverbank filtration. Chemosphere 76, 1167-1177. doi: 10.1016/j.chemosphere.2009. 06.043

Ziganshin, A. M., Gerlach, R., Borch, T., Naumov, A. V., and Naumova, R. P. (2007). Production of eight different hydride complexes and nitrite release from 2,4,6-trinitrotoluene by Yarrowia lipolytica. Appl. Environ. Microbiol. 73, 7898-7905. doi: 10.1128/AEM.01296-07

Zoh, K.-D., and Stenstrom, M. K. (2002). Fenton oxidation of hexahydro1,3,5-trinitro-1,3,5-triazine (RDX) and octahydro-1,3,5,7-tetranitro-1,3,5,7tetrazocine (HMX). Water Res. 36, 1331-1341. doi: 10.1016/S0043-1354 (01)00285-8

Conflict of Interest Statement: The authors declare that the research was conducted in the absence of any commercial or financial relationships that could be construed as a potential conflict of interest.

The reviewer JB and handling Editor declared their shared affiliation.

Copyright (C) 2018 Beck, Gledhill, Schlosser, Stamer, Böttcher, Sternheim, Greinert and Achterberg. This is an open-access article distributed under the terms of the Creative Commons Attribution License (CC BY). The use, distribution or reproduction in other forums is permitted, provided the original author(s) and the copyright owner are credited and that the original publication in this journal is cited, in accordance with accepted academic practice. No use, distribution or reproduction is permitted which does not comply with these terms. 